\title{
Comparison of key absorption and optical properties between pure and transported anthropogenic dust over East and Central Asia
}

\author{
Jianrong Bi ${ }^{1}$, Jianping Huang ${ }^{1}$, Brent Holben ${ }^{2}$, and Guolong Zhang ${ }^{1}$ \\ ${ }^{1}$ Key Laboratory for Semi-Arid Climate Change of the Ministry of Education, College of Atmospheric Sciences, \\ Lanzhou University, Lanzhou, 730000, China \\ ${ }^{2}$ NASA Goddard Space Flight Center, Greenbelt, Maryland, USA \\ Correspondence to: Jianping Huang (hjp@1zu.edu.cn)
}

Received: 24 August 2016 - Published in Atmos. Chem. Phys. Discuss.: 7 September 2016

Revised: 9 November 2016 - Accepted: 23 November 2016 - Published: 15 December 2016

\begin{abstract}
Asian dust particulate is one of the primary aerosol constituents in the Earth-atmosphere system that exerts profound influences on environmental quality, human health, the marine biogeochemical cycle, and Earth's climate. To date, the absorptive capacity of dust aerosol generated from the Asian desert region is still an open question. In this article, we compile columnar key absorption and optical properties of mineral dust over East and Central Asian areas by utilizing the multiyear quality-assured datasets observed at 13 sites of the Aerosol Robotic Network (AERONET). We identify two types of Asian dust according to threshold criteria from previously published literature. (1) The particles with high aerosol optical depth at $440 \mathrm{~nm}\left(\mathrm{AOD}_{440} \geq 0.4\right)$ and a low Ångström wavelength exponent at $440-870 \mathrm{~nm}(\alpha<0.2)$ are defined as Pure Dust (PDU), which decreases disturbance of other non-dust aerosols and keeps high accuracy of pure Asian dust. (2) The particles with $\mathrm{AOD}_{440} \geq 0.4$ and $0.2<\alpha<0.6$ are designated as Transported Anthropogenic Dust (TDU), which is mainly dominated by dust aerosol and might mix with other anthropogenic aerosol types. Our results reveal that the primary components of high AOD days are predominantly dust over East and Central Asian regions, even if their variations rely on different sources, distance from the source, emission mechanisms, and meteorological characteristics. The overall mean and standard deviation of single-scattering albedo, asymmetry factor, real part and imaginary part of complex refractive index at $550 \mathrm{~nm}$ for Asian PDU are $0.935 \pm 0.014,0.742 \pm 0.008,1.526 \pm 0.029$, and $0.00226 \pm 0.00056$, respectively, while corresponding values are $0.921 \pm 0.021,0.723 \pm 0.009,1.521 \pm 0.025$, and $0.00364 \pm 0.0014$ for Asian TDU. Aerosol shortwave di-
\end{abstract}

rect radiative effects at the top of the atmosphere (TOA), at the surface (SFC), and in the atmospheric layer (ATM) for Asian PDU $(\alpha<0.2)$ and TDU $(0.2<\alpha<0.6)$ computed in this study, are a factor of 2 smaller than the results of Optical Properties of Aerosols and Clouds (OPAC) mineral-accumulated (mineral-acc.) and mineral-transported (mineral-tran.) modes. Therefore, we are convinced that our results hold promise for updating and improving accuracies of Asian dust characteristics in present-day remote sensing applications and regional or global climate models.

\section{Introduction}

Airborne dust particles (also called mineral dust) are recognized as one of the most important aerosol species in the tropospheric atmosphere, which accounts for about $30 \%$ of the total aerosol loading and extinction aerosol optical depth on a global scale (Perlwitz et al., 2001; Kinne et al., 2006; Chin et al., 2009; Huang et al., 2014). High concentrations of dust aerosols hanging over desert source regions and invasive downstream areas would seriously exacerbate air quality, degrade visibility, affect transportation safety, and have adverse effects on public health during the prevalent seasons of dust storms (Chan et al., 2008; Morman and Plumlee, 2013; Wang et al., 2016). When mineral dusts are deposited onto the Earth's surface, they play a key role in biogeochemical cycles of terrestrial or ocean ecosystems (Okin et al., 2004; Jickells et al., 2005; Shao et al., 2011), as well as alter snow and ice albedo (Aoki et al., 2006; Huang et al., 2011; Wang et al., 2013). Last but not least, dust particles can modulate 
the Earth's energy budget and drive climate change directly by scattering and absorbing solar and/or terrestrial radiation (Charlson et al., 1992; H. Wang et al., 2010; Huang et al., 2014) and indirectly by acting as effective cloud condensation nuclei or ice nuclei, influencing the cloud microphysics and precipitation processes (Ramanathan et al., 2001; Rosenfeld et al., 2001; DeMott et al., 2003; J. Huang et al., 2005, 2006, 2010; W. Wang et al., 2010; Creamean et al., 2013). Numerous studies (Sokolik and Toon, 1999; Lafon et al., 2004, 2006) have confirmed that dust particle is one kind of light-absorbing substance, and its mass absorption efficiencies at $325 \mathrm{~nm}\left(0.06-0.12 \mathrm{~m}^{2} \mathrm{~g}^{-1}\right)$ are about 6 times larger than that at $660 \mathrm{~nm}\left(0.01-0.02 \mathrm{~m}^{2} \mathrm{~g}^{-1}\right)$, owing to the greater absorbing potential of iron oxides at short wavelengths (Alfaro et al., 2004). However, the way iron oxides mix with quartz or clay is complicated and strongly impacts the resulting absorption (Claquin et al., 1998, 1999; Sokolik and Toon, 1999). Furthermore, these mineralogical studies indicate that a lack of consideration of these mixing mechanisms is a significant limitation of the previous dust absorption computations. Although the absorptive ability of dust is two orders of magnitude lower than for black carbon (Yang et al., 2009), the atmospheric mass loading of the former is the same magnitude larger than that of the latter, leading to a total absorption in solar spectrum comparable to black carbon. Chin et al. (2009) found that dust may account for about $53 \%$ of global averaged aerosol absorption optical depth at $550 \mathrm{~nm}$, which undoubtedly changes the aforementioned dust-cloudprecipitation interaction and exerts a significant effect on the hydrological cycle of the Earth-atmosphere system.

East and Central Asian territories, which produce a large amount of dust particles every year that become entrained into the upper atmosphere by cold fronts, are the major source regions of dust aerosols on Earth (Zhang et al., 1997; J. Huang et al., 2009, 2010, 2014). They can travel over thousands of kilometers, even across the Pacific Ocean, and reach the western coast of North America in about 1 week with the prevailing westerly wind (Husar et al., 2001; Uno et al., 2009, 2011). They then modify the climate and environment over extensive areas of the Asia-Pacific rim. Thus far, there have been a great deal of fruitful field campaigns for exploring Asian dust (e.g., U.S.S.R.-U.S., ACE-Asia, ADEC, PACDEX, EAST-AIRC); however, most focus on intensive observation period (Golitsyn and Gillette, 1993; Huebert et al., 2003; Nakajima et al., 2003; Mikami et al., 2006; Huang et al., 2008a; Li et al., 2011) and lack of long-term quantitative knowledge of dust optical, microphysical characteristics (especially absorption properties) and chemical compositions over these regions. Hence, the absorptive capacity of Asian dust aerosol is still an outstanding issue. The variations in dust optical features in model calculations are closely related to the uncertainties in particle size distribution and prescribing a value for complex refractive index. Whereas the key parameters of Asian dust aerosols in present-day climate models are still prescribed to the predetermined properties of Saharan mineral dust.

Wang et al. (2004) inferred the refractive index of pure minerals at Qira in the Taklimakan Desert during 12-14 April 2002 via a combination of theoretical calculation and composition analysis of aerosol samples and showed that the value of the imaginary part is 0.00411 at $500 \mathrm{~nm}$, which is consistent with the Central Asian dust of $0.004 \pm 0.001$ (Tajikistan desert; Sokolik and Golitsyn, 1993). Uchiyama et al. (2005) determined the single-scattering albedo (SSA) of Aeolian dust from sky radiometer and in situ measurements, and concluded that unpolluted Aeolian dust (source from the Taklimakan Desert) has low absorption (with SSA500 of 0.930.97). Kim et al. (2004) analyzed multiyear sky radiation measurements over East Asian sites of the sky radiometer network (Nakajima et al., 1996; Takamura et al., 2004) and showed that the $\mathrm{SSA}_{500}$ of dust particles is around 0.9 in arid Dunhuang in northwestern China and Mandalgovi in the Gobi desert in Mongolia. Bi et al. (2014) also reported a similar SSA $_{550}(0.91-0.97)$ of dust aerosol at Dunhuang during spring of 2012. Xu et al. (2004) got a SSA530 of $0.95 \pm 0.05$ in Yulin, China, from a Radiance Research nephelometer and a particle soot absorption photometer (PSAP) and suggested that both desert dust and local pollution sources contributed to the aerosol loading in Yulin during April 2001. Whereas Ge et al. (2010) examined dust aerosol optical properties at Zhangye (a semiarid area of northwestern China) with a multifilter rotating shadowband radiometer (MFRSR) during spring of 2008 and found that although there are low aerosol optical depth values $\left(\mathrm{AOD}_{670}\right.$ ranging from 0.07 to 0.25), dust particles have strong absorption (with $\mathrm{SSA}_{500}$ of $0.75 \pm 0.02$ ) due to mixing with local anthropogenic pollutants. This result is similar to that over New Delhi in India (0.74-0.84 for $\mathrm{SSA}_{500}$; Pandithurai et al., 2008). Lafon et al. (2006) revealed that due to containing less calcite and a higher fraction of iron oxide-clay aggregates, mineral dusts in Niger (Banizoumbou, 13 $31^{\prime} \mathrm{N}, 2^{\circ} 38^{\prime} \mathrm{E}$ ) have a much lower SSA in the visible wavelengths than those of Chinese (Ulan Buh Shamo, 39 $26^{\prime} \mathrm{N}, 105^{\circ} 40^{\prime} \mathrm{E}$ ) and Tunisian (Maouna, 33 $01^{\prime} \mathrm{N}, 10^{\circ} 40^{\prime} \mathrm{E}$ ) desert locations. Therefore, complete clarification of the climate-relevant impacts of Asian dust aerosols requires extensive and long-term measurements of optical, microphysical, and chemical properties, along with their spatial and temporal distributions.

There have been several world-famous aerosol longterm monitoring networks over Asian regions for examining aerosol features and its radiative effects, for instance, AERONET (AErosol RObotic NETwork) (Holben et al., 1998), SKYNET (aerosol-cloud-radiation interaction ground-based observation network) (Nakajima et al., 1996; Takamura et al., 2004; Che et al., 2008), and CARSNET (China Aerosol Remote Sensing Network) (Che et al., 2009a, 2014, 2015). In this paper, we investigate optical characteristics of Asian dust from multiyear AERONET measurements at 13 sites in and around arid or semiarid regions of East 
and Central Asian desert sources. The key quantities include single-scattering albedo (SSA), asymmetry factor (ASY), real part $(\mathrm{Re})$ and imaginary part $(\mathrm{Ri})$ of complex refractive index, and volume size distribution $(\mathrm{d} V / \mathrm{d} \ln r)$, which are needed for climate simulation and remote sensing applications. We mainly compare the vital absorption and optical properties between pure and transported anthropogenic dust over East and Central Asia. This article is arranged as follows. Section 2 introduces the site description and measurements. The identification method and detailed Asian dust optical features are described in Sect. 3. Discussion of spectral absorption behaviors of different dust aerosol types are given in Sect. 4 and followed by the Summary in Sect. 5 .

\section{Site description and measurement}

\subsection{Site description}

In this article, we select 13 AERONET sites located in arid or semiarid Asian regions (see Fig. 1), which are recognized as the primarily active centers of dust storms. These drylands are very sensitive to climate change and human activities and would accelerate drought expansion by the end of the twenty-first century (Zheng et al., 2009; Huang et al., 2016). Eight sites over the East Asian region are labeled with red colors, and five sites over the Central Asian area are labeled with blue colors. The major deserts along with plateaus are marked in black font (e.g., Gobi desert in Mongolia, Taklimakan Desert, Thar Desert, Karakum Desert, Tibetan Plateau, Loess Plateau, and Iranian Plateau). In order to quantitatively explore detailed spectral absorptive characteristics of dust aerosols over East and Central Asia, we chose four East Asian sites (SACOL, Dalanzadgad, Beijing, and Yulin) and four Central Asian sites (Dushanbe, Karachi, Kandahar, and IASBS). They consist of SACOL located over the Loess Plateau of northwestern China (Huang et al., 2008b; Guan et al., 2009; Z. Huang et al., 2010; G. Wang et al., 2010), Dalanzadgad in the Gobi desert of southern Mongolia (Eck et al., 2005), Beijing downwind of Inner Mongolia (Xia et al., 2007), Yulin on the southwestern fringe of the $\mathrm{Mu}$ Us Desert in northwestern China (Xu et al., 2004; Che et al., 2009b, 2015), Dushanbe in Tajikistan situated at the transport corridor of Central Asian desert dust (i.e., Karakum Desert; Golitsyn and Gillette, 1993), Karachi located in the southern margin of the Thar Desert in Pakistan and about $20 \mathrm{~km}$ from the eastern coast of the Arabian Sea (Alam et al., 2011), Kandahar in the arid area of southern Afghanistan, and IASBS on the Iranian Plateau in northwestern Iran.

\subsection{Sun photometer measurements}

AERONET is an internationally federated global groundbased aerosol monitoring network, which comprises more than 500 sites all over the world utilizing a Cimel sun photometer (Holben et al., 1998). The Cimel Electronique

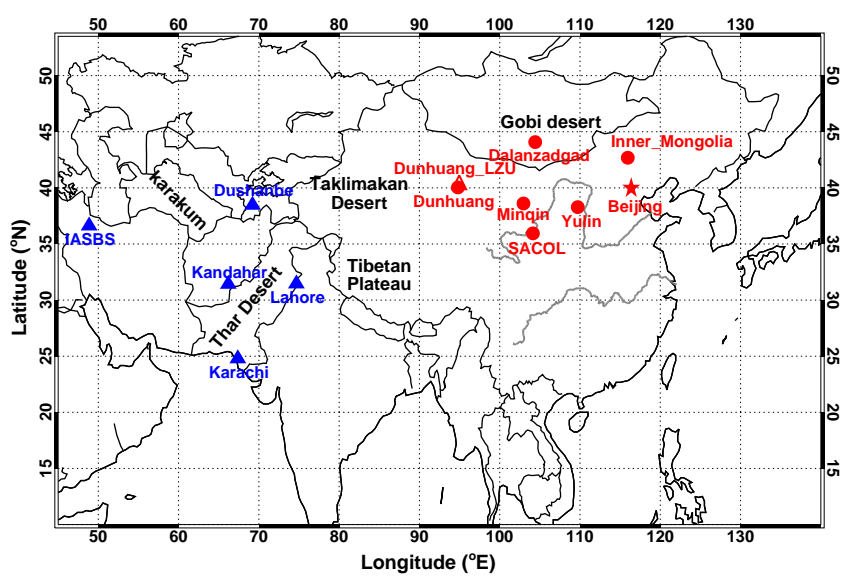

Figure 1. Geographical location of selected 13 AERONET sites in this study. Eight sites over the East Asian region are labeled with red colors, and five sites over the Central Asian region are labeled with blue colors. The major deserts along with plateaus are marked in black font.

sun photometer (CE-318) takes measurements of sun direct irradiances at multiple discrete channels within the spectral range of $340-1640 \mathrm{~nm}$, which can be used to calculate aerosol optical depth (AOD) and columnar water vapor content (WVC) in centimeters. Furthermore, the instrument can perform angular distribution of sky radiances at 440, 675, 870, and $1020 \mathrm{~nm}$ (nominal wavelengths), which can be simultaneously retrieved aerosol volume size distribution, complex refractive index, single-scattering albedo, and asymmetry factor under cloudless conditions (Dubovik and King, 2000; Dubovik et al., 2002a, 2006). The total accuracy in AOD for a newly calibrated field instrument is about 0.010-0.021 (Eck et al., 1999). The retrieval errors of SSA, ASY, Ri, and Re are anticipated to be 0.03-0.05, 0.04, 30$50 \%$, and $0.025-0.04$, respectively, relying on aerosol types and loading (Dubovik et al., 2000). It should be kept in mind that these uncertainties are valid for $\mathrm{AOD}_{440} \geq 0.4$ and for solar zenith angle $>50^{\circ}$ (level 2.0 product), and the retrieval errors will become much greater when $\mathrm{AOD}_{440}<0.4$. The datasets of the selected 13 AERONET sites in this study come from the level 2.0 product and are pre- and post-field calibrated, automatically cloud screened, and quality assured (Smirnov et al., 2000). In addition, a mixture of randomly oriented polydisperse spheroid particle shape assumptions with a fixed aspect ratio distribution is applied to retrieve key optical properties of Asian dust (Dubovik, et al., 2002a, 2006). Fu et al. (2009) concluded that Mie-based singlescattering properties of spheroidal dust aerosols are well suited in radiative flux calculations. 

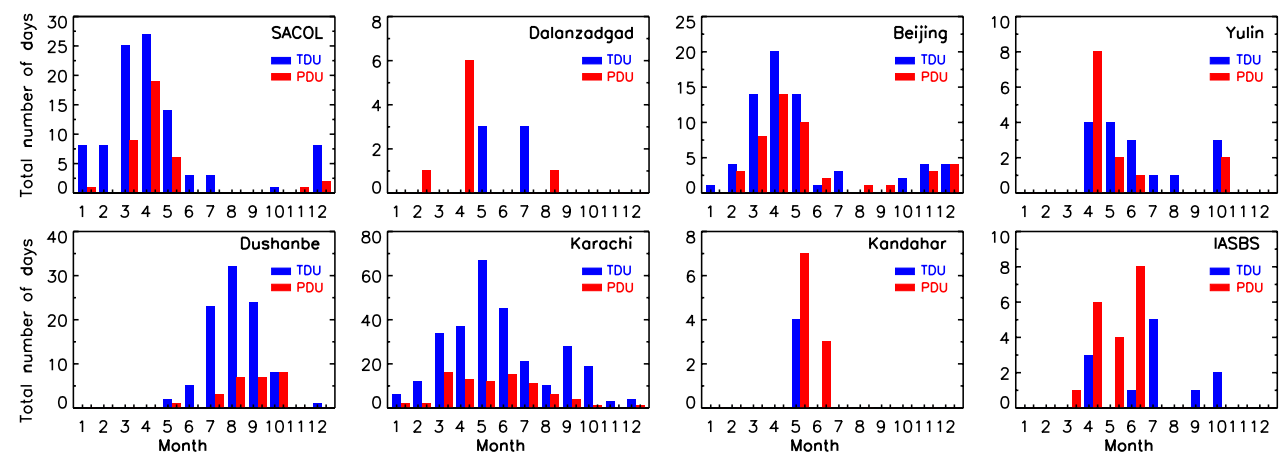

Figure 2. Occurrence frequency of total number days for Pure Dust ( $\alpha<0.2$, PDU with red color) and Transported Anthropogenic Dust $(0.2<\alpha<0.6$, TDU with blue color) at four selected East Asian sites (top panel) and four Central Asian sites (bottom panel).

\section{Asian dust optical properties}

A great number of publications have verified that mineral dust aerosols are commonly dominated by large particles with coarse mode (radii $>0.6 \mu \mathrm{m}$ ), which is the essential feature differentiating the dust from fine-mode-dominated biomass burning and urban-industrial aerosols (Dubovik et al., 2002b; Eck et al., 2005; Bi et al., 2011, 2014; Kim et al., 2011; Che et al., 2013). In other words, the values of the Angström exponent at $440-870 \mathrm{~nm}(\alpha)$ for dust aerosols usually range between -0.1 and 0.6 . As pointed out by Smirnov et al. (2002) and Dubovik et al. (2002b), sea salt aerosol is also dominated by coarse mode and has a small Ångström exponent $(\sim 0.3-0.7)$ but with low $\mathrm{AOD}_{440}(\sim 0.15-0.2)$ compared with dust aerosol. Moreover, the selected desert locations in this study are mostly not affected by sea salt. By virtue of these differences, we can distinguish Asian dust aerosols from other fine-modedominated non-dust particles. The criteria of two thresholds are put forward. (1) The particles with high aerosol optical depth at $440 \mathrm{~nm}\left(\mathrm{AOD}_{440} \geq 0.4\right)$ and a low Ångström wavelength exponent at $440-870 \mathrm{~nm}(\alpha<0.2)$ are defined as Pure Dust (PDU) that keeps high accuracy of pure Asian dust and eliminates most fine-mode aerosols. (2) The particles with $\mathrm{AOD}_{440} \geq 0.4$ and $0.2<\alpha<0.6$ are designated as Transported Anthropogenic Dust (TDU), which is mainly dominated by dust and might mix with other anthropogenic aerosol types during transportation. The definition of anthropogenic dust in this study is different from earlier literature (Tegen and Fung, 1995; Prospero et al., 2002; Huang et al., 2015), which define anthropogenic dust as primarily produced by various human activities on disturbed soils (e.g., agricultural practices, industrial activity, transportation, desertification, and deforestation). It is still a huge challenge to discriminate between natural and anthropogenic components of dust aerosols using current technology, AERONET products, or in situ measurements. Recently, Ginoux et al. (2012) first estimated that anthropogenic sources globally account for $25 \%$ based on Moderate Resolution Imaging Spectrora- diometer (MODIS) Deep Blue dust optical depth in conjunction with other land-use datasets. Huang et al. (2015) proposed a new algorithm for distinguishing anthropogenic dust from natural dust by using Cloud-Aerosol Lidar and Infrared Pathfinder Satellite Observation (CALIPSO) and planetary boundary layer (PBL) height retrievals along with MODIS land cover dataset. They revealed that anthropogenic dust produced by human activities mainly comes from semiarid and semi-humid regions and is generally mixed with other types of aerosols within the PBL that are more spherical than natural dust. Thereby, we assume that anthropogenic dust aerosol originating from Asian arid or semiarid areas has smaller size distribution (thus a larger Ångström exponent) than that of pure natural dust.

Before insight into dust aerosol optical characteristics, we first analyze the occurrence frequency of Asian dust over the study region, which significantly affects the intensity and distribution of mineral dust loading. Figure 2 depicts the total number of days of each month for Pure Dust $(\alpha<0.2)$ and transported Anthropogenic Dust $(0.2<\alpha<0.6)$ at four selected East Asian sites and four Central Asian sites. The dust events at the four East Asian sites primarily concentrate on springtime and corresponding peak days for PDU and TDU both appear in April. This is greatly attributed to the intrusion of dust particles during spring when dust storms are prevalent over these regions (Wang et al., 2008). For the SACOL and Beijing sites, both the PDU and TDU days occur during the whole year except for the rainy season in autumn, which is linked with long-range transport of dust particulates from desert source areas and local anthropogenic dust (e.g., agricultural cultivation, overgrazing, desertification, industrial, and constructed dust in urbanization). Shen et al. (2016) demonstrated that urban fugitive dust generated by road transport and urban construction contributes to more than $70 \%$ of particulate matter $\left(\mathrm{PM}_{2.5}\right)$ in northern China. The dust episodes in Dushanbe of Tajikistan mostly happen from July to October, which are the peak seasons of dust storms (Golitsyn and Gillette, 1993). For the Karachi site in Pakistan, dust activities take place in the spring and sum- 
Table 1. Overall average and standard deviation of key optical properties at $550 \mathrm{~nm}$ (e.g., single-scattering albedo, asymmetry factor, and real part and imaginary part of complex refractive index) for Asian Pure Dust (PDU). Angström wavelength exponent ( $\alpha$ ) is in the range of $440-870 \mathrm{~nm}$. Minimum and maximum values of the optical properties are in parentheses for each corresponding column. Measuring period and the total number of PDU $(\alpha<0.2)$ and TDU $(0.2<\alpha<0.6)$ days are in parentheses for the first and last column, respectively.

\begin{tabular}{|c|c|c|c|c|c|c|}
\hline $\begin{array}{l}\text { Site } \\
\text { (sampled period) }\end{array}$ & $\begin{array}{r}\text { SSA } \\
(\min , \max )\end{array}$ & $\begin{array}{r}\text { ASY } \\
(\min , \max )\end{array}$ & $\begin{array}{r}\mathrm{Re} \\
(\min , \max )\end{array}$ & $\begin{array}{r}\mathrm{Ri} \\
\left(\times 10^{-3}\right)\end{array}$ & $\begin{array}{r}\text { Ångström } \\
(440-870 \mathrm{~nm})\end{array}$ & $\begin{array}{r}\text { PDU/days } \\
\text { (TDU) }\end{array}$ \\
\hline $\begin{array}{l}\text { SACOL } \\
(2006-2012)\end{array}$ & $\begin{array}{l}0.932 \pm 0.018 \\
(0.888,0.971)\end{array}$ & $\begin{array}{l}0.741 \pm 0.012 \\
(0.715,0.771)\end{array}$ & $\begin{array}{r}1.534 \pm 0.044 \\
(1.438,1.60)\end{array}$ & $\begin{array}{r}2.251 \pm 0.788 \\
(0.913,5.51)\end{array}$ & $\begin{array}{r}0.120 \pm 0.049 \\
(0.0,0.198)\end{array}$ & $\begin{array}{r}38 \\
(97)\end{array}$ \\
\hline $\begin{array}{l}\text { Dalanzadgad } \\
(1997-2014)\end{array}$ & $\begin{array}{l}0.930 \pm 0.012 \\
(0.912,0.949)\end{array}$ & $\begin{array}{l}0.746 \pm 0.010 \\
(0.724,0.766)\end{array}$ & $\begin{array}{r}1.512 \pm 0.046 \\
(1.447,1.60)\end{array}$ & $\begin{array}{r}2.407 \pm 0.414 \\
(1.649,3.19)\end{array}$ & $\begin{array}{r}0.127 \pm 0.079 \\
(-0.06,0.199)\end{array}$ & $\begin{array}{r}8 \\
(6)\end{array}$ \\
\hline $\begin{array}{l}\text { Beijing } \\
(2001-2015)\end{array}$ & $\begin{array}{l}0.917 \pm 0.020 \\
(0.863,0.963)\end{array}$ & $\begin{array}{l}0.742 \pm 0.012 \\
(0.716,0.769)\end{array}$ & $\begin{array}{r}1.557 \pm 0.043 \\
(1.401,1.60)\end{array}$ & $\begin{array}{r}2.801 \pm 0.865 \\
(1.032,6.20)\end{array}$ & $\begin{array}{r}0.117 \pm 0.067 \\
(-0.048,0.199)\end{array}$ & $\begin{array}{r}46 \\
(67)\end{array}$ \\
\hline $\begin{array}{l}\text { Yulin } \\
(2001-2002)\end{array}$ & $\begin{array}{l}0.907 \pm 0.024 \\
(0.863,0.952)\end{array}$ & $\begin{array}{l}0.748 \pm 0.010 \\
(0.731,0.771)\end{array}$ & $\begin{array}{r}1.559 \pm 0.038 \\
(1.476,1.60)\end{array}$ & $\begin{array}{r}3.564 \pm 1.589 \\
(1.370,7.92)\end{array}$ & $\begin{array}{r}0.077 \pm 0.068 \\
(-0.024,0.188)\end{array}$ & $\begin{array}{r}13 \\
(16)\end{array}$ \\
\hline $\begin{array}{l}\text { Dushanbe } \\
(2010-2015)\end{array}$ & $\begin{array}{l}0.941 \pm 0.012 \\
(0.916,0.959)\end{array}$ & $\begin{array}{l}0.739 \pm 0.011 \\
(0.710,0.765)\end{array}$ & $\begin{array}{r}1.529 \pm 0.041 \\
(1.436,1.60)\end{array}$ & $\begin{array}{l}2.011 \pm 0.551 \\
(1.022,3.475)\end{array}$ & $\begin{array}{r}0.128 \pm 0.054 \\
(-0.02,0.198)\end{array}$ & $\begin{array}{r}26 \\
(95)\end{array}$ \\
\hline $\begin{array}{l}\text { Karachi } \\
(2006-2014)\end{array}$ & $\begin{array}{l}0.945 \pm 0.012 \\
(0.916,0.977)\end{array}$ & $\begin{array}{l}0.741 \pm 0.011 \\
(0.714,0.767)\end{array}$ & $\begin{array}{r}1.518 \pm 0.030 \\
(1.449,1.60)\end{array}$ & $\begin{array}{l}1.938 \pm 0.561 \\
(0.758,3.439)\end{array}$ & $\begin{array}{r}0.141 \pm 0.041 \\
(-0.005,0.20)\end{array}$ & $\begin{array}{r}83 \\
(286)\end{array}$ \\
\hline $\begin{array}{l}\text { Lahore } \\
(2007-2015)\end{array}$ & $\begin{array}{l}0.930 \pm 0.014 \\
(0.901,0.957)\end{array}$ & $\begin{array}{l}0.740 \pm 0.010 \\
(0.721,0.765)\end{array}$ & $\begin{array}{r}1.519 \pm 0.038 \\
(1.432,1.60)\end{array}$ & $\begin{array}{l}2.253 \pm 0.611 \\
(1.207,3.623)\end{array}$ & $\begin{array}{l}0.136 \pm 0.052 \\
(0.023,0.198)\end{array}$ & $\begin{array}{r}26 \\
(248)\end{array}$ \\
\hline $\begin{array}{l}\text { IASBS } \\
(2010-2013)\end{array}$ & $\begin{array}{l}0.933 \pm 0.017 \\
(0.883,0.958)\end{array}$ & $\begin{array}{l}0.725 \pm 0.011 \\
(0.704,0.746)\end{array}$ & $\begin{array}{r}1.572 \pm 0.024 \\
(1.525,1.60)\end{array}$ & $\begin{array}{l}2.290 \pm 0.845 \\
(1.245,5.029)\end{array}$ & $\begin{array}{l}0.098 \pm 0.050 \\
(0.021,0.195)\end{array}$ & $\begin{array}{r}19 \\
(12)\end{array}$ \\
\hline $\begin{array}{l}\text { Kandahar } \\
(2008 / 04-06)\end{array}$ & $\begin{array}{l}0.925 \pm 0.013 \\
(0.903,0.955)\end{array}$ & $\begin{array}{l}0.729 \pm 0.017 \\
(0.700,0.768)\end{array}$ & $\begin{array}{r}1.534 \pm 0.035 \\
(1.492,1.60)\end{array}$ & $\begin{array}{r}2.855 \pm 0.775 \\
(1.445,4.65)\end{array}$ & $\begin{array}{r}0.147 \pm 0.054 \\
(0.00,0.199)\end{array}$ & $\begin{array}{l}10 \\
(4)\end{array}$ \\
\hline $\begin{array}{l}\text { Dunhuang } \\
(2001 / 03-05)\end{array}$ & $\begin{array}{l}0.947 \pm 0.015 \\
(0.918,0.970)\end{array}$ & $\begin{array}{l}0.745 \pm 0.013 \\
(0.723,0.761)\end{array}$ & $\begin{array}{r}1.547 \pm 0.037 \\
(1.494,1.60)\end{array}$ & $\begin{array}{r}1.714 \pm 0.697 \\
(1.014,3.14)\end{array}$ & $\begin{array}{r}0.039 \pm 0.029 \\
(-0.003,0.091)\end{array}$ & $\begin{array}{r}6 \\
(0)\end{array}$ \\
\hline $\begin{array}{l}\text { Dunhuang_LZU } \\
(2012 / 04-05)\end{array}$ & $\begin{array}{l}0.958 \pm 0.007 \\
(0.951,0.968)\end{array}$ & $\begin{array}{l}0.741 \pm 0.021 \\
(0.707,0.771)\end{array}$ & $\begin{array}{l}1.495 \pm 0.042 \\
(1.451,1.580)\end{array}$ & $\begin{array}{r}1.589 \pm 0.292 \\
(1.092,1.84)\end{array}$ & $\begin{array}{l}0.153 \pm 0.026 \\
(0.117,0.184)\end{array}$ & $\begin{array}{r}5 \\
(4)\end{array}$ \\
\hline $\begin{array}{l}\text { Inner_Mongolia } \\
(2001 / 04-05)\end{array}$ & $\begin{array}{l}0.948 \pm 0.012 \\
(0.930,0.960)\end{array}$ & $\begin{array}{l}0.751 \pm 0.006 \\
(0.743,0.759)\end{array}$ & $\begin{array}{r}1.499 \pm 0.042 \\
(1.426,1.54)\end{array}$ & $\begin{array}{r}1.641 \pm 0.457 \\
(1.169,2.45)\end{array}$ & $\begin{array}{l}0.069 \pm 0.054 \\
(0.011,0.165)\end{array}$ & $\begin{array}{r}4 \\
(1)\end{array}$ \\
\hline $\begin{array}{l}\text { Minqin } \\
(2010 / 05-06)\end{array}$ & $\begin{array}{l}0.945 \pm 0.002 \\
(0.942,0.947)\end{array}$ & $\begin{array}{l}0.756 \pm 0.014 \\
(0.740,0.764)\end{array}$ & $\begin{array}{l}1.469 \pm 0.023 \\
(1.449,1.494)\end{array}$ & $\begin{array}{r}2.036 \pm 0.220 \\
(1.883,2.29)\end{array}$ & $\begin{array}{l}0.119 \pm 0.023 \\
(0.103,0.146)\end{array}$ & $\begin{array}{r}2 \\
(0)\end{array}$ \\
\hline Overall mean & $0.935 \pm 0.014$ & $0.742 \pm 0.008$ & $1.526 \pm 0.029$ & $2.258 \pm 0.556$ & $0.113 \pm 0.033$ & PDU \\
\hline Overall mean & $0.921 \pm 0.021$ & $0.723 \pm 0.009$ & $1.521 \pm 0.025$ & $3.643 \pm 1.372$ & $0.355 \pm 0.06$ & TDU \\
\hline
\end{tabular}

mer seasons. This is because the region is not affected by the summer monsoon, leaving the land surface sufficiently dry, and hence susceptible to wind erosion by strong winds and mesoscale thunderstorm events typical of this time of year (Alizadeh Choobari et al., 2014). In addition, the transport of summer dust plumes from the Arabian Peninsula can partially contribute dust particles to the Karachi site. Note that the months of PDU cases are different from TDU cases at the Dalanzadgad, Kandahar, and IASBS sites, suggesting that dust aerosols over these areas are rarely affected by anthropogenic pollutants. For the Kandahar site in Afghanistan, the limited sampling days may affect the statistical results to some extent. Generally, the aforementioned occurrence frequency of dust storms over diverse sites are principally dependent on different climatic regime and synoptic pattern, for instance, geographical location, atmospheric circulation, wet season and dry season.

Table 1 summarizes the site information, sampling period, overall average optical properties at $550 \mathrm{~nm}$ (e.g., SSA, ASY, Re, Ri, and Ångström exponent at 440-870 nm) for Asian PDU $(\alpha<0.2)$ and the total number of PDU and TDU $(0.2<\alpha<0.6)$ days. Note that dust optical feature at a common $550 \mathrm{~nm}$ wavelength, which can be derived from logarithmic interpolation between 440 and $675 \mathrm{~nm}$, is utilized here. It 

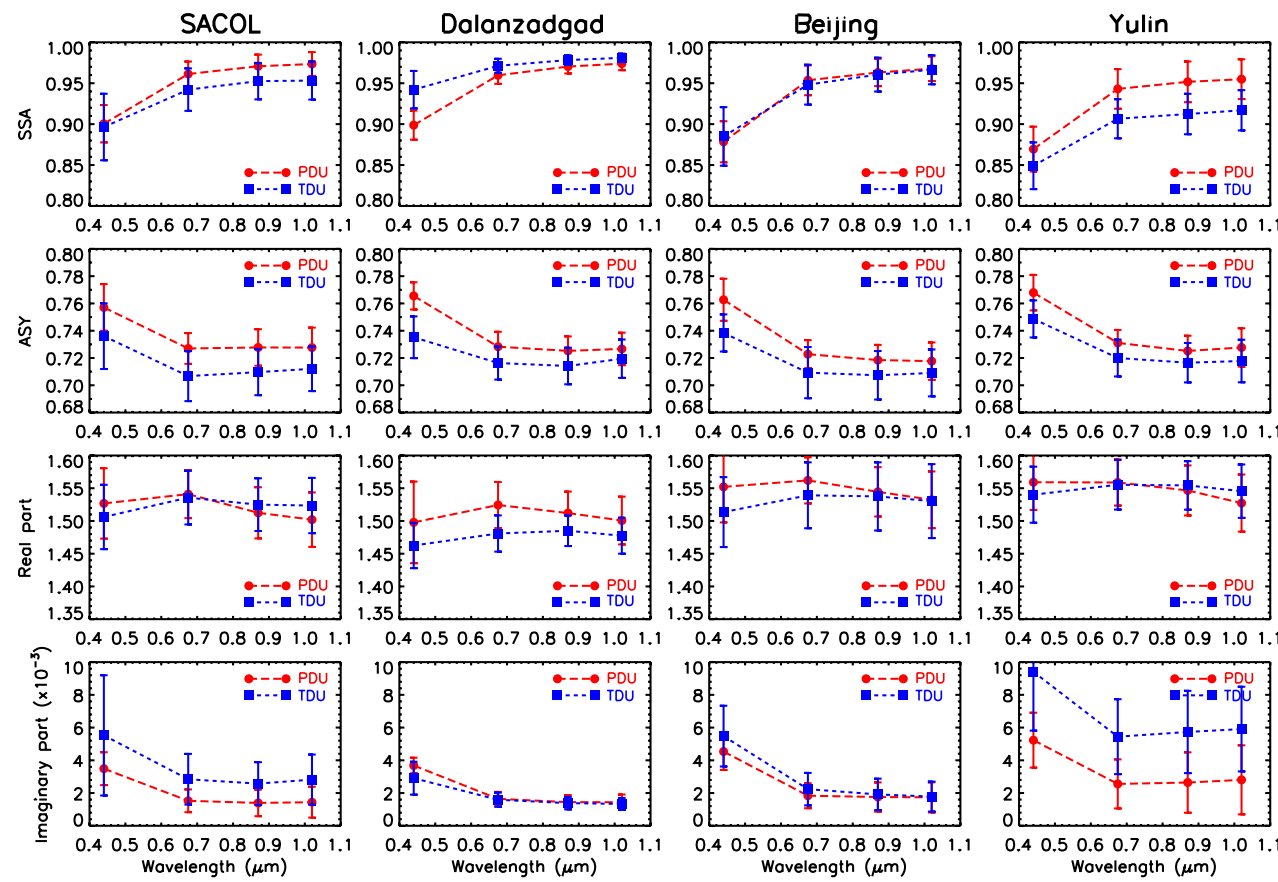

Figure 3. Overall average spectral behavior of key optical properties for Pure Dust $(\alpha<0.2$, PDU with red circle) and Transported Anthropogenic Dust $(0.2<\alpha<0.6$, TDU with blue square) at four selected East Asian sites (SACOL, Dalanzadgad, Beijing, and Yulin). The error bars indicate plus or minus one standard deviation.

is worth pointing out that the absorption and optical properties of dust aerosols at two Dunhuang sites exhibit consistent features despite different sampling periods, which indicates that the chemical composition of dust aerosol in the Dunhuang area remains relatively stable.

The SSA or Ri of complex refractive index can characterize the absorptive capability of dust aerosols and determine the sign (cooling or heating, depending on the planetary albedo) of the radiative forcing (Hansen et al., 1997). Both quantities mainly rely on the ferric oxide content in mineral dust (Sokolik and Toon, 1999). Figure 3 illustrates the overall average spectral behavior of key optical properties for PDU $(\alpha<0.2)$ and TDU $(0.2<\alpha<0.6)$ at four selected East Asian sites. The SSA, ASY, Re, and Ri of complex refractive index as a function of wavelength $(440,675,870$, and $1020 \mathrm{~nm})$ are presented. For all cases, the spectral behaviors of aerosol optical parameters exhibit similar features, which can be representative of typical patterns of Asian dust. The SSA values systematically increase with wavelength at $440-675 \mathrm{~nm}$ and keep an almost neutral or slight increase for the wavelengths greater than $675 \mathrm{~nm}$, which is consistent with the previous results of dust aerosols (Dubovik et al., 2002b; Eck et al., 2005; Bi et al., 2011). In contrast, an opposite pattern is displayed by the imaginary part of the refractive index; namely, Ri values dramatically decrease from 440 to $675 \mathrm{~nm}$ and preserve the invariant from 675 to $1020 \mathrm{~nm}$. These variations indicate that Asian dust aerosols have a much stronger absorptive ability at shorter wavelengths. Alfaro et al. (2004) implied that the absorption capacity of soil dust increases linearly with iron oxide content, and estimated SSA at $325 \mathrm{~nm}$ $(\sim 0.80)$ is much lower than that at $660 \mathrm{~nm}(\sim 0.95)$. Sokolik and Toon (1999) revealed that ferric iron oxides (e.g., hematite and goethite) are often internally mixed with clay minerals and result in significant dust absorption in the UV and or visible wavelengths. Hence, the spectral variations of SSA and Ri with wavelengths are attributable to the domination of coarse-mode dust particles that have larger light absorption in the blue spectral band, as mentioned above. It is worth noting that spectral ASY values remarkably reduce from 440 to $675 \mathrm{~nm}$ and are almost constant at 675 $1020 \mathrm{~nm}$ range. This suggests that Asian dust aerosols have much stronger scattering at $440 \mathrm{~nm}$ than other longer visible wavebands due to the contribution of coarse-mode particles. By contrast, the spectral behavior of Re is not obvious for PDU and TDU at all sites, and the mean Re values at $440 \mathrm{~nm}$ vary between 1.50 and 1.56 . Although there are 18 years of continuous AERONET datasets at the Dalanzadgad site, the effective days of PDU and TDU are only 8 and 6 days, respectively, almost only appearing in springtime. There are no identifiable differences for dust absorption properties between PDU and TDU cases for Dalanzadgad, which indicates again that the site is hardly influenced by anthropogenic pollutants. The spectral discrepancies of optical characteristics between PDU and TDU at three other sites are much more apparent than at Dalanzadgad, which is ascribed to the fact that these regions are not only affected by dust aerosols, but 


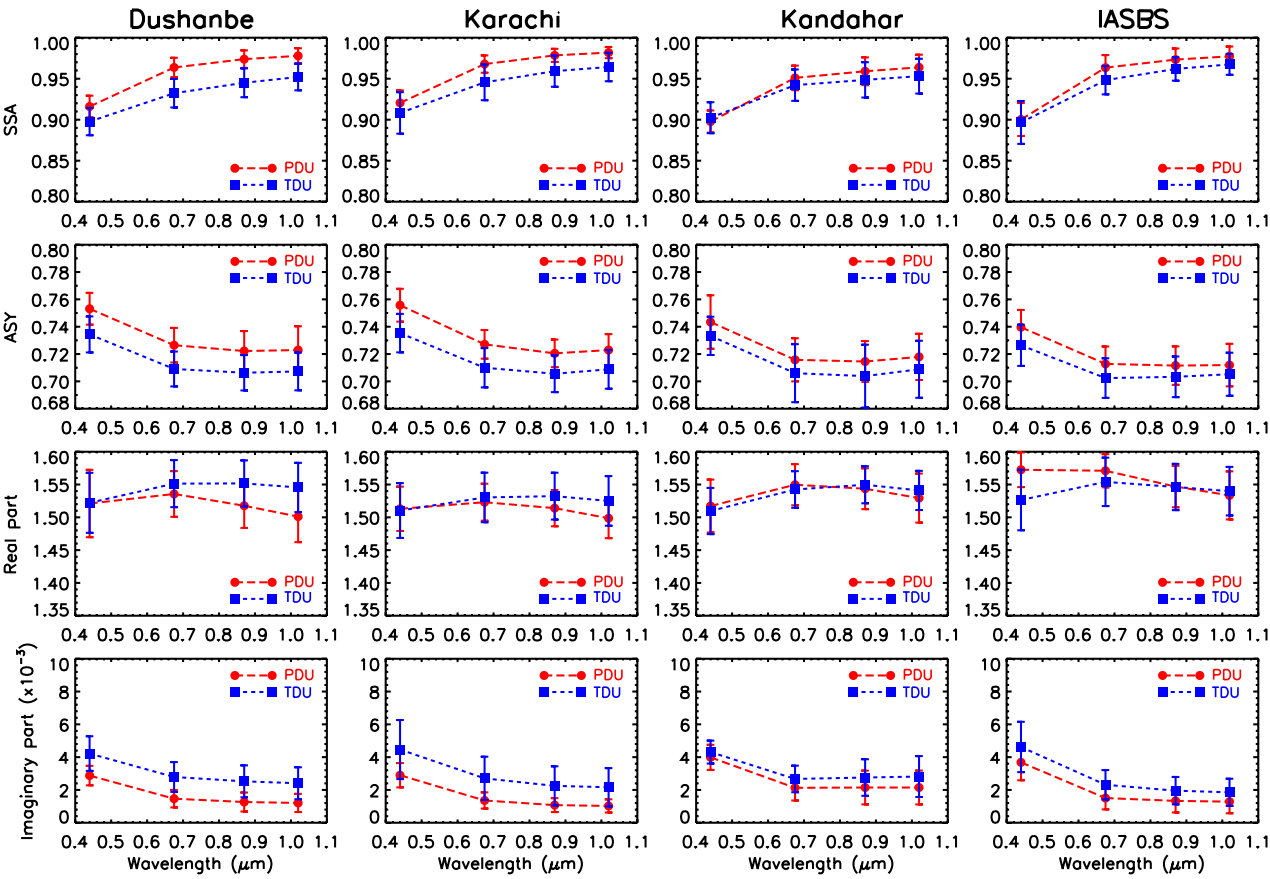

Figure 4. The same as Fig. 3, but for four selected Central Asian sites (Dushanbe, Karachi, Kandahar, and IASBS).

also by local anthropogenic emissions, for instance, urban industry, coal fuel combustion, biomass burning, mobile source emissions, and agricultural dust (Xu et al., 2004; Xia et al., 2007; Che et al., 2015; Bi et al., 2011; Wang et al., 2015).

Figure 4 is the same as Fig. 3, but for four selected Central Asian sites. The wavelength dependencies of PDU and TDU cases at Central Asian sites are consonant with that of East Asian sites, despite variations in magnitude and amplitude. This is expected because the East Asian desert sites are very close to the Central Asian desert locations and retain similar chemical compositions of dust aerosols (Wang et al., 2004). The spectral behaviors of dust optical properties for PDU at the Kandahar and IASBS sites are nearly the same as the TDU cases, which agrees well with the consistent variability of occurrence of dust storms. The wavelength dependency of dust characteristics for PDU at Dushanbe and Karachi presents large differences with the TDU case, which is also likely due to the influence of local anthropogenic pollution. Furthermore, the standard deviation of PDU is far less than that of TDU at all wavelengths, suggesting that the robustness of the PDU recognition method.

Particle size distribution is another critical agent for deciding the optical and radiative properties of dust aerosol. Nakajima et al. (1996) and Dubovik and King (2000) uncovered that based on the spherical Mie theory, the retrieval errors of volume size distribution do not exceed $10 \%$ for intermediate particle size $(0.1 \leq r \leq 7 \mu \mathrm{m})$ and may greatly increase to $35-100 \%$ at the edges of size range $(r<0.1 \mu \mathrm{m}$ or $r>7 \mu \mathrm{m})$. As mentioned above, a polydisperse, randomly oriented spheroid method is utilized in this study, which is demonstrated to remove the artificially increased size distribution of fine-particle mode with $\mathrm{AOD}_{440} \geq 0.4$ and for solar zenith angle $>50^{\circ}$. Additionally, the large errors at the edges do not significantly affect the derivation of the main features of the particle size distribution (concentration, median and effective radii, etc.) because typical dust aerosol size distributions have low values at the edges of retrieval size interval (Dubovik et al., 2002a). Figure 5 delineates the overall average columnar aerosol volume size distributions $(\mathrm{d} V / \mathrm{d} \ln r, 0.05 \mu \mathrm{m} \leq r \leq 15 \mu \mathrm{m})$ for Pure Dust $(\alpha<0.2)$ and Transported Anthropogenic Dust $(0.2<\alpha<0.6)$ at 13 selected AERONET sites. Corresponding $\mathrm{AOD}_{440}$ and effective radius of coarse mode $\left(r_{\text {coarse }}\right)$ in $\mu \mathrm{m}$ are also shown. It is apparent that the $\mathrm{d} V / \mathrm{d} \ln r$ exhibits a typical bimodal structure and is dominated by coarse mode for PDU and TDU at all sites. The $\mathrm{d} V / \mathrm{d} \ln r$ peak of coarse-mode particles varies dramatically and appears at a radius $r_{\mathrm{Vc}} \sim 2.24 \mu \mathrm{m}$ for all PDU cases and $r_{\mathrm{Vc}} \sim 2.0-3.0 \mu \mathrm{m}$ for TDU cases, while the corresponding peak of fine-mode particles arises at a radius $r_{\mathrm{Vf}} \sim 0.09-0.12 \mu \mathrm{m}$. The $\mathrm{d} V / \mathrm{d} \ln r$ peak and effective radius $\left(r_{\text {coarse }}\right)$ of coarse-mode particles strikingly increase with the increase of AOD ascribed to the intrusion of dust particles. For instance, the $\mathrm{AOD}_{440} \mathrm{~d} V / \mathrm{d} \ln r$ peak values of coarse mode, and $r_{\text {coarse }}$ for PDU at the Minqin site are 0.48 , $0.31 \mu \mathrm{m}^{3} \mu \mathrm{m}^{-2}$, and $1.74 \mu \mathrm{m}$, respectively, and corresponding values are $1.13,0.77 \mu \mathrm{m}^{3} \mu \mathrm{m}^{-2}$, and $1.93 \mu \mathrm{m}$ at the Lahore site, as shown in Fig. 5a. The average volume median radii of fine-mode and coarse-mode particles for PDU are 0.159 and $2.157 \mu \mathrm{m}$, respectively, and 0.140 and $2.267 \mu \mathrm{m}$ for TDU (see Table 2). The mean volume concentration ratio 

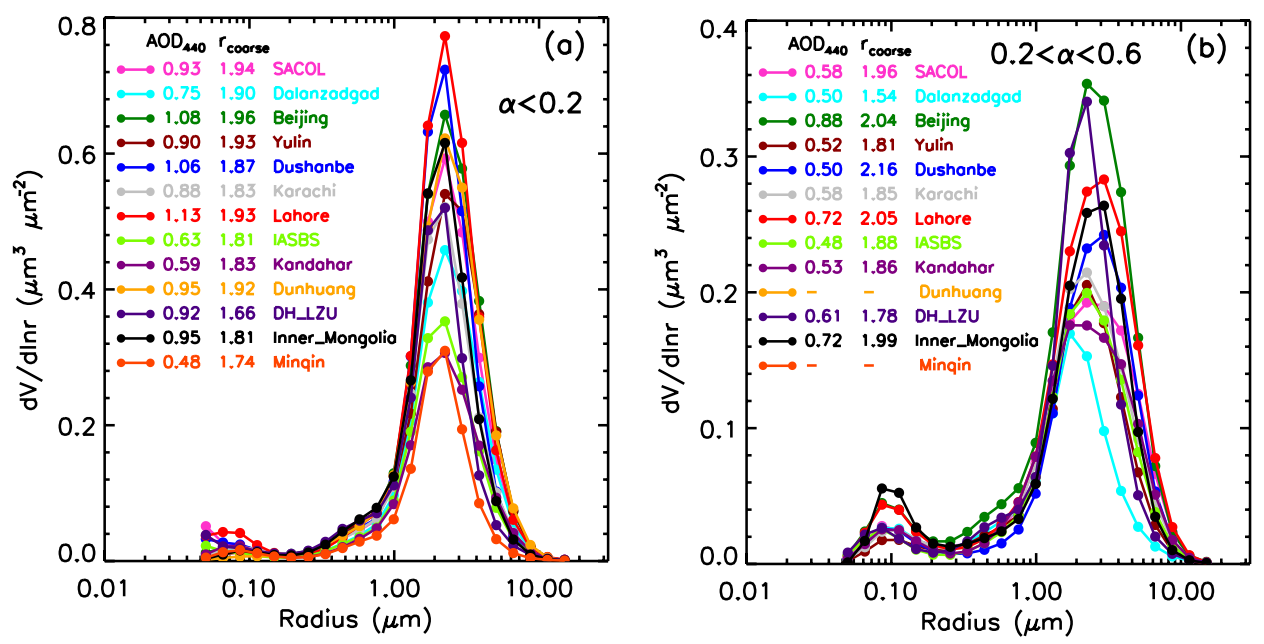

Figure 5. Overall average of aerosol volume size distributions in the entire atmospheric column for (a) Pure Dust $(\alpha<0.2)$ and (b) Transported Anthropogenic Dust $(0.2<\alpha<0.6)$ at 13 selected AERONET sites. Corresponding aerosol optical depth at $440 \mathrm{~nm}\left(\mathrm{AOD}_{440}\right)$ and effective radius of coarse mode $\left(r_{\text {coarse }}\right)$ in $\mu \mathrm{m}$ are also shown. Note that the "-" in panel (b) represents missing data for AOD 440 and $r_{\text {coarse }}$ at the Dunhuang and Minqin sites.

Table 2. Spectral optical properties of Pure Dust $(\alpha<0.2)$ and Transported Anthropogenic Dust $(0.2<\alpha<0.6)$ averaged for 13 sites over East and Central Asian areas.

\begin{tabular}{lrr}
\hline Asian dust & Pure dust $(\alpha<0.2)$ & Transported anthropogenic dust $(0.2<\alpha<0.6)$ \\
\hline$\omega_{0}(440 / 675 / 870 / 1020)$ & $0.906 / 0.962 / 0.971 / 0.975 \pm 0.009$ & $0.897 / 0.943 / 0.954 / 0.959 \pm 0.019$ \\
$\operatorname{Re}(440 / 675 / 870 / 1020)$ & $1.520 / 1.533 / 1.517 / 1.503 \pm 0.026$ & $1.509 / 1.533 / 1.532 / 1.525 \pm 0.027$ \\
$\operatorname{Ri}(440 / 675 / 870 / 1020) \times 10^{-3}$ & $3.413 / 1.574 / 1.449 / 1.449 \pm 0.450$ & $5.064 / 2.737 / 2.510 / 2.486 \pm 1.300$ \\
$\mathrm{ASY}(440 / 675 / 870 / 1020)$ & $0.758 / 0.727 / 0.724 / 0.726 \pm 0.008$ & $0.736 / 0.711 / 0.710 / 0.712 \pm 0.009$ \\
$r_{\mathrm{Vf}}(\mu \mathrm{m}) ; \sigma_{\mathrm{f}}$ & $0.159 \pm 0.029$ & $0.140 \pm 0.011$ \\
$r_{\mathrm{Vc}}(\mu \mathrm{m}) ; \sigma_{\mathrm{c}}$ & $2.157 \pm 0.112$ & $2.267 \pm 0.214$ \\
$C_{\mathrm{Vf}}\left(\mu \mathrm{m}^{3} \mu \mathrm{m}^{-2}\right)$ & $0.037 \pm 0.011 ; 0.06 \times \tau(1020)-0.001$ & $0.038 \pm 0.011 ; 0.12 \times \tau(1020)-0.014$ \\
$C_{\mathrm{Vc}}\left(\mu \mathrm{m}^{3} \mu \mathrm{m}^{-2}\right)$ & $0.632 \pm 0.167 ; 0.88 \times \tau(1020)-0.07$ & $0.343 \pm 0.084 ; 0.90 \times \tau(1020)-0.06$ \\
$C_{\mathrm{Vc}} / C_{\mathrm{Vf}}$ & $17.9(11-31)$ & $9.1(5-11)$ \\
\hline
\end{tabular}

Each variable is accompanied by a standard deviation (e.g., \pm 0.01 ). $r_{\mathrm{Vf}}$ and $r_{\mathrm{Vc}}$ are the volume median radii of fine-mode and coarse-mode particles in $\mu$ m; $C_{\mathrm{Vf}}$ and $C_{\mathrm{Vc}}$ denote the volume concentrations of fine-mode and coarse-mode particles in $\mu \mathrm{m}^{3} \mu \mathrm{m}^{-2}$, respectively. The dynamic dependencies of dust optical properties are exhibited as functions of $\mathrm{AOD}_{1020}$, with correlation coefficients greater than 0.93 for all cases.

of coarse-mode to fine-mode particles $\left(C_{\mathrm{Vc}} / C_{\mathrm{Vf}}\right)$ for Pure Dust is about 18 (varying between 11 and 31) over East and Central Asia, which is close to the average of $\sim 20$ at Dunhuang_LZU during spring of 2012 (Bi et al., 2014) and much less than that over Saharan pure desert domain $(\sim 50)$ (Dubovik et al., 2002b). The $\mathrm{d} V / \mathrm{d} \ln r$ peak of coarse mode for TDU is clearly smaller than that for PDU, and the corresponding mean $C_{\mathrm{Vc}} / C_{\mathrm{Vf}}$ value is $9(\sim 5-11)$. We attribute the high fractions of coarse-mode particles to high AOD and low Ångström exponent values.

In this paper, we postulate that Asian dust particles only possess scattering and absorption characteristics. The absorption AOD value (AAOD) at a specific wavelength can also be obtained from SSA and AOD, namely, $\mathrm{AAOD}_{\lambda}=$ $\left(1-\mathrm{SSA}_{\lambda}\right) \times \mathrm{AOD}_{\lambda}$, where $\lambda$ is the wavelength. Thereby, the corresponding absorption Ångström exponent (AAE) at 440 -
$870 \mathrm{~nm}$ is calculated from spectral AAOD values by using a $\log$-linear fitting algorithm. Figure 6 outlines the total average Ångström exponent $(\alpha)$ and absorption Ångström exponent at $440-870 \mathrm{~nm}$, volume concentration of coarse mode in $\mu \mathrm{m}^{3} \mu \mathrm{m}^{-2}$, and volume median radius of coarse mode in $\mu \mathrm{m}$ for TDU $(0.2<\alpha<0.6)$ and PDU $(\alpha<0.2)$ at selected AERONET sites. There are very big differences in all quantities between PDU and TDU cases, except for some sites (e.g., Dunhuang and Minqin). The primary reason is that we only acquired limited datasets of dust days during springtime at the Dunhuang and Minqin sites, which are hardly affected by other anthropogenic pollutants. The AE values of TDU show remarkable changes among the sites, ranging from 0.24 to 0.44; whereas, corresponding values of PDU keep comparatively slight variations for 13 selected sites $(\sim 0.04-0.15)$. Furthermore, all the AAE values of PDU are greater than 1.5, 

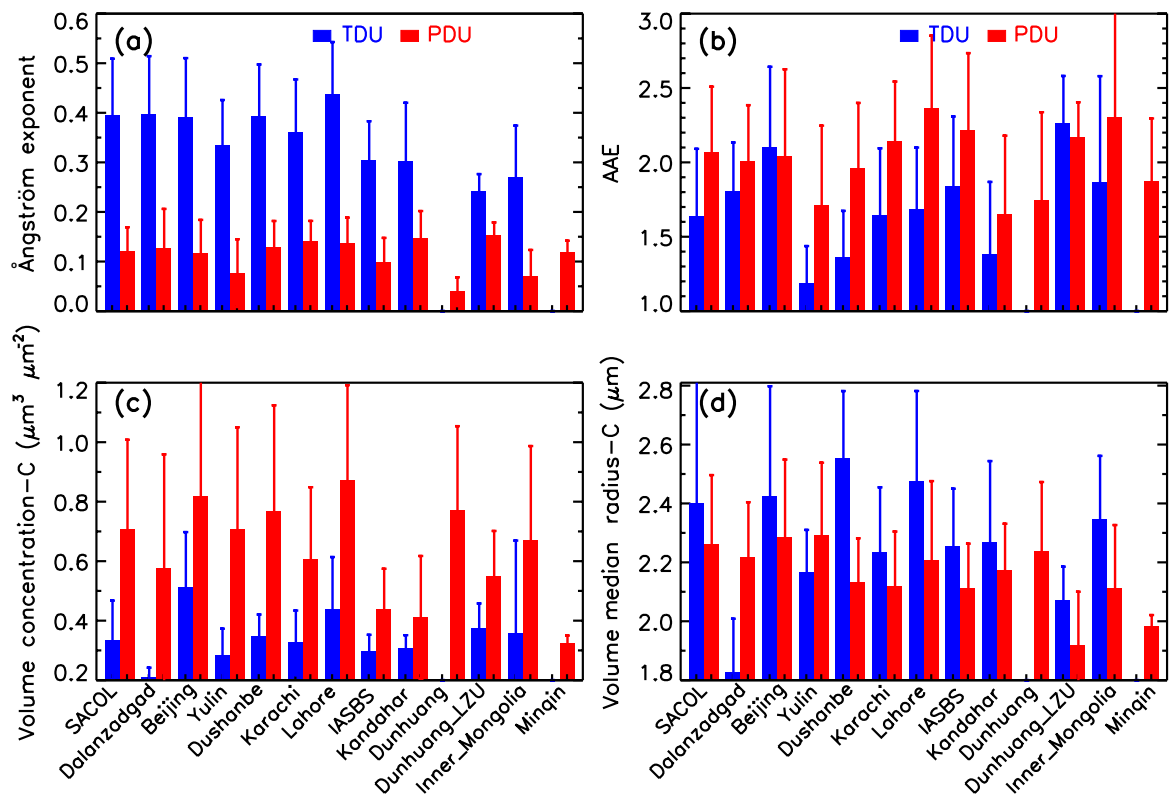

Figure 6. Total average values of (a) Ångström exponent (440-870 nm), (b) absorption Ångström exponent (AAE) at 440-870 nm, (c) volume concentration of coarse mode $\left(\mu \mathrm{m}^{3} \mu \mathrm{m}^{-2}\right)$, and (d) volume median radius of coarse mode in $\mu \mathrm{m}$ for Transported Anthropogenic Dust $(0.2<\alpha<0.6$, blue color) and Pure Dust $(\alpha<0.2$, red color) at 13 selected AERONET sites. The error bars indicate plus or minus one standard deviation.

ranging between 1.65 and 2.36, and the AAE of TDU varies from 1.2 to 2.3. We can conclude that the Asian Pure Dust aerosols have AE values smaller than 0.2 and corresponding AAE larger than 1.50, which is another typical feature distinguishing Asian Pure Dust aerosols from other non-dust aerosols. Yang et al. (2009) attributed the high AAE values of dust aerosol in China to the presence of ferric oxides. It is evident that volume concentrations of coarse mode for PDU are significantly higher than the TDU, which is expected for the more coarse-mode particles in PDU. Conversely, the volume median radius of coarse mode for TDU is greater than PDU, although there are some smaller values for TDU at the Dalanzadgad and Yulin sites. This is because dust particles at these sites usually mix with other anthropogenic aerosol species and substantially enhance their median radii.

Figure 7 characterizes the overall mean optical properties (e.g., SSA, ASY, Re, and Ri) at $440 \mathrm{~nm}$ for 13 selected sites. In general, the absorption capacity of PDU is less than that for TDU, that is, higher SSA and smaller Ri values for PDU, except for at the Dalanzadgad site. A reasonable interpretation is that the threshold criterion method for PDU in this study has effectively eliminated the finemode aerosols, which are mostly the much stronger absorbing aerosols (e.g., soot and biomass burning aerosol) over East and Central Asia but are the weaker absorbing pollution aerosols (i.e., sulfate and nitrate) over Dalanzadgad. $\mathrm{Wu}$ et al. $(2012,2014)$ documented that sulfate and nitrate in background atmosphere most likely originated directly from surface soil at the northern and southern edges of the Taklimakan Desert and comprised steadily about $4 \%$ of dust particulate matters, which could partially explain our results. Additionally, the overall mean ASY and Re of PDU are greater than that of TDU, which again verifies that the Asian Pure Dust has much stronger forward scattering ability than the mixture of Asian dust. Note that the standard deviation of SSA and Ri for PDU is a factor of 24 lower than that of TDU. Furthermore, the total average values of SSA, ASY, Re, and Ri at $550 \mathrm{~nm}$ wavelength for Asian PDU are $0.935 \pm 0.014,0.742 \pm 0.008,1.526 \pm 0.029$, and $0.00226 \pm 0.00056$, respectively, while corresponding values are $0.921 \pm 0.021,0.723 \pm 0.009,1.521 \pm 0.025$, and $0.00364 \pm 0.0014$ for TDU. Yang et al. (2009) took advantage of various in situ aerosol optical and chemical measurements at Xianghe, China, during the EAST-AIRC campaign and deduced a refractive index of $1.53-0.0023 i$ at $550 \mathrm{~nm}$ of dust aerosol, which is close to the results for PDU in this study. Nevertheless, the TDU case should be much closer to actual airborne dust aerosol in the real world. When the elevated dusts over desert source regions are transported eastward, they generally mix with other chemical species and react heterogeneously with anthropogenic pollutants, and thus may significantly modify their chemical composition and microphysical properties (Arimoto et al., 2004). Recently, Kim et al. (2011) found that the annual mean SSA, ASY, $\mathrm{Re}$, and $\mathrm{Ri}$ of complex refractive index for nearly pure Saharan dust are $0.944 \pm 0.005,0.752 \pm 0.014,1.498 \pm 0.032$, and $0.0024 \pm 0.0034$ at $550 \mathrm{~nm}$, respectively, which are close 

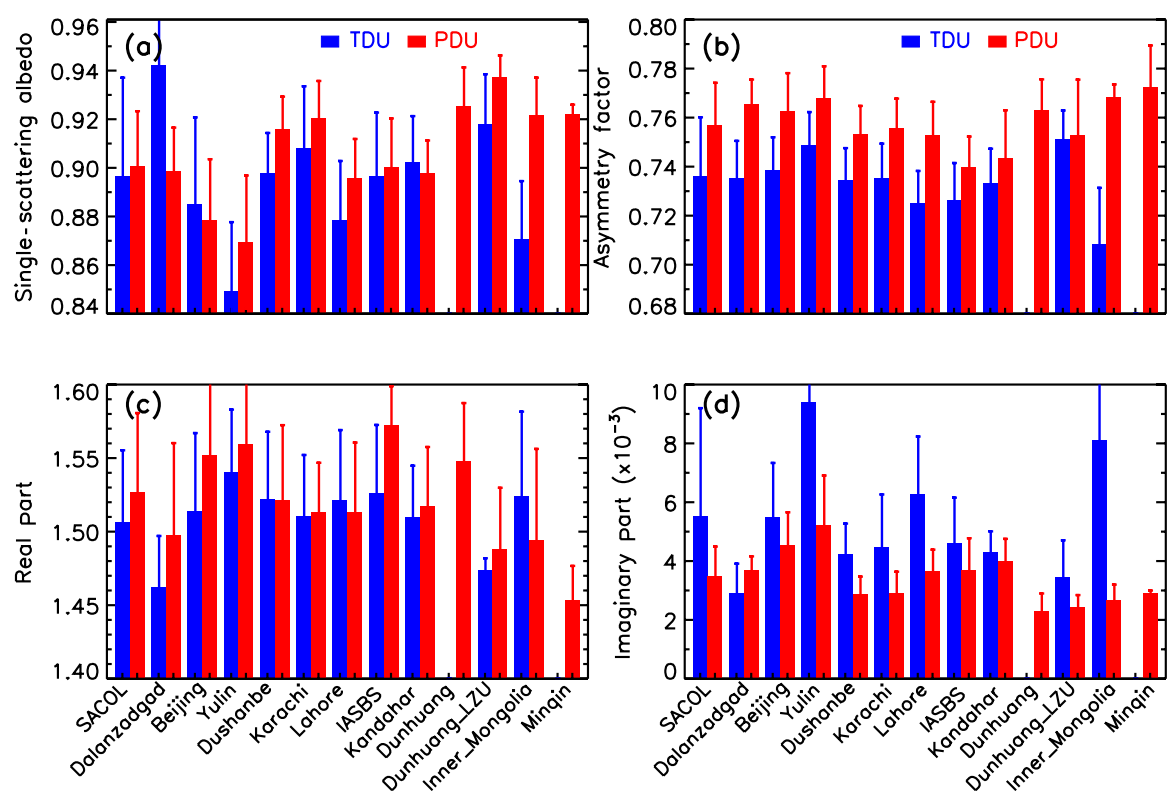

Figure 7. The same as Fig. 5, but for (a) single-scattering albedo, (b) asymmetry factor, and (c) real part and (d) imaginary part of complex refractive index at $440 \mathrm{~nm}$.

to our results of pure Asian dust but exist some differences of quantitative values and spectral behaviors.

Average spectral optical properties (at 440, 675, 870, and $1020 \mathrm{~nm}$ ) for PDU and TDU over East and Central Asian regions are tabulated in Table 2. To our knowledge, this is the first table built on Asian dust optical characteristics utilizing multiyear and multisite AERONET measurements, which will hopefully improve uncertainties of Asian dust shortwave radiative forcing in current regional and global climate models.

\section{Discussion}

Figure 8 describes the mean spectral behaviors of Re, RI, and SSA for Asian Pure Dust $(\alpha<0.2)$ in this study along with published dust results over various geographical locations (Carlson and Caverly, 1977 or C77; Patterson et al., 1977 or P77; WMO, 1983; Hess et al., 1998 or OPAC; Dubovik et al., 2002b or Persian Gulf; Alfaro et al., 2004 or Ulan Buh Shamo desert; Wang et al., 2004 or ADEC; Todd et al., 2007 or T07). It is well known that a lot of presentday dust models commonly take advantage of the Optical Properties of Aerosols and Clouds (OPAC; Hess et al., 1998) or World Meteorological Organization (WMO, 1983) databases. Curves $\mathrm{C} 77$ and P77 show the complex refractive index of Saharan dust in Cabo Verde, Barbados, and Tenerife, Canary Islands, obtained from laboratory analysis by Carlson and Caverly (1977) and Patterson et al. (1977), respectively. Curve P77 gives one of the most widely used datasets of Ri values in the range $300-700 \mathrm{~nm}$. Curve Persian Gulf
(98-00) displays the refractive index and SSA of dust over Bahrain-Persian Gulf desert during 1998-2000 derived from Dubovik et al. (2002b). Curve T07 shows the optical properties of mineral dust over the Bodélé Depression of northern Chad during 2005 retrieved by a Cimel sun photometer by Todd et al. (2007). The curves ADEC and Ulan Buh Shamo desert exhibit the dust absorptive properties over aforementioned Taklimakan and Ulan Buh Shamo deserts of northwestern China according to Wang et al. (2004) and Alfaro et al. (2004). Figure 8a shows that the spectral behaviors of Re have relatively slight variations with values ranging from 1.50 to 1.56 , apart from T07, which shows lower Re values of 1.44-1.47. Todd et al. (2007) utilized scanning electron microscope (SEM) analysis of airborne dust material and confirmed that the mineral dust is dominated by fragmented fossil diatoms from the dry lake bed of the Bodélé Depression, which is to some extent different from typical desert soil. As shown in Fig. 8b, wavelength dependences of Ri exhibit comparably greater differences in UV wavebands. In mid-visible and near infrared wavelengths, our results are slightly larger than Persian Gulf (98-00) and T07 that were retrieved from a Cimel sun photometer, but they are still comparable. It is very distinct that the absorption ability of Asian Pure Dust $(\alpha<0.2)$ in the whole spectrum range is about a factor of 4 smaller than current dust models (WMO, 1983; Hess et al., 1998), and it is a factor of 2 to 3 lower than the results from in situ measurements combined with laboratory analysis or model calculations (Carlson and Caverly, 1977; Patterson et al., 1977; Wang et al., 2004). Meanwhile, the wavelength dependences of SSA agree well with the Persian Gulf (98-00) 

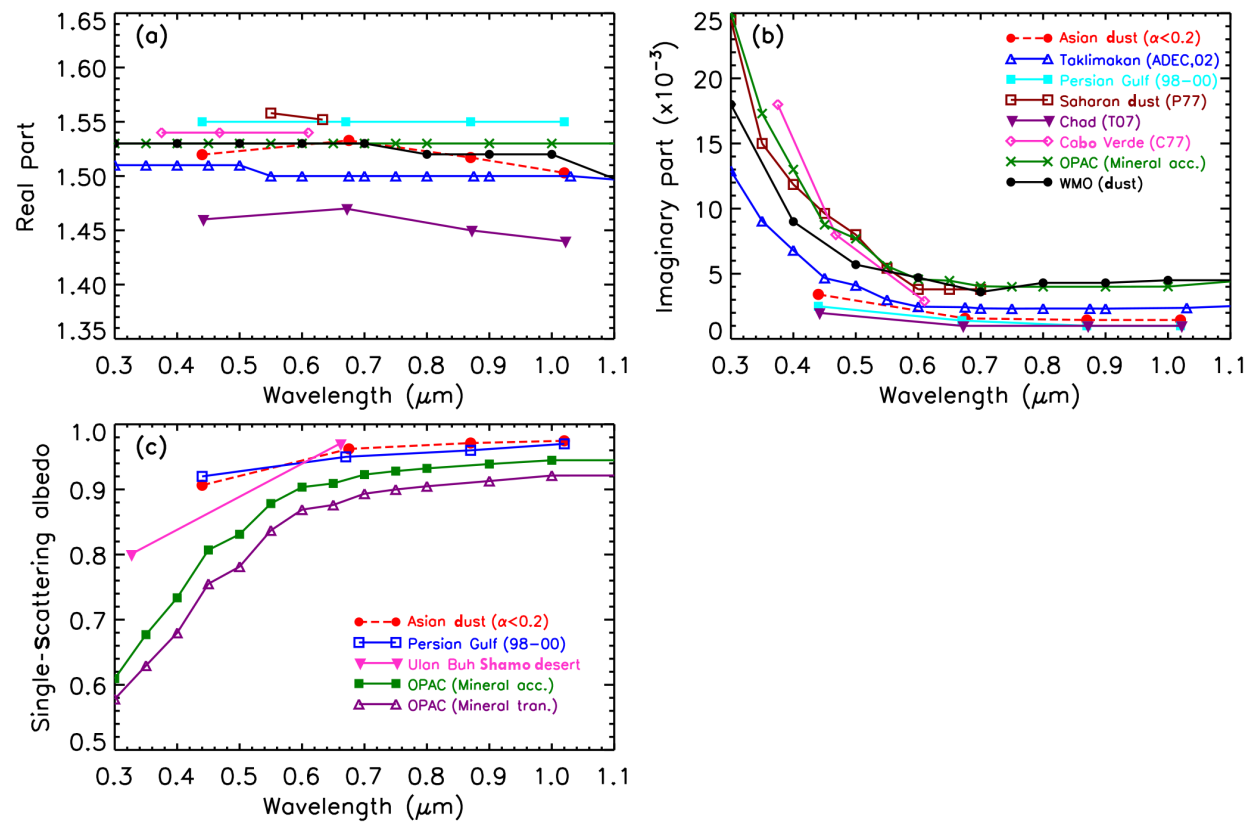

Figure 8. Mean spectral behaviors of (a) real part and (b) imaginary part of complex refractive index and (c) single-scattering albedo for Asian Pure Dust $(\alpha<0.2)$ calculated for 13 AERONET sites, and results of current common dust models (OPAC, WMO). Bahrain-Persian Gulf desert dust (1998-2000), Saharan dust (Chad, Cabo Verde), and Chinese Gobi desert (Taklimakan Desert, Ulan Buh Shamo desert) are also shown for comparison.

and Ulan Buh Shamo desert results, but are much higher than OPAC. The discrepancy increases dramatically with decreasing wavelength. Such big differences in dust absorption capacity for diverse dust models (OPAC and WMO) and studies will certainly lead to different radiative impacts on regional or global climate change.

Figure 9 draws the aerosol shortwave direct radiative effects (ARF) at the top of atmosphere (TOA), at the surface (SFC), and in the atmospheric layer (ATM) for Asian Pure Dust $(\alpha<0.2)$ and Transported Anthropogenic Dust $(0.2<\alpha<0.6)$ acquired in this study, and corresponding ARF values for OPAC mineral-accumulated (mineral-acc.) and mineral-transported (mineral-tran.) modes are also presented for comparison. We make use of the Santa Barbara Discreteordinate Atmospheric Radiative Transfer model (SBDART, Ricchiazzi et al., 1998) to calculate the ARF, which has been proved to be a reliable software code and is widely used for simulating plane-parallel radiative fluxes in the Earth's atmosphere (Halthore et al., 2005; Bi et al., 2013). The main input parameters of spectral AOD, surface albedo, WVC, and columnar ozone amount are prescribed to the same values (e.g., $0.72,0.30,1.0 \mathrm{~cm}$, and $300 \mathrm{DU}$ for input $\mathrm{AOD}_{440}$, surface albedo, WVC, and ozone amount), and the spectral SSA, ASY, Re, and Ri values are obtained from the various aforementioned dust models. It is evident that Earth's energy budget is modulated and redistributed by different absorbing properties of mineral dusts. The results indicate that the cooling rate at the surface (negative radiative forcing) gradually increases with PDU $(\alpha<0.2)$, TDU $(0.2<\alpha<0.6)$, OPAC mineral-accumulated and mineral-transported dust modes. By contrast, the cooling intensity at TOA gradually decreases with diverse dust cases and even becomes positive radiative forcing for OPAC transported dust mode, with ARF varying from $-15.6,-13.8,-6.9$, and $+0.24 \mathrm{~W} \mathrm{~m}^{-2}$, respectively. Therefore, the heating intensity in the atmospheric layer sharply increases from $+22.7,+29.5,+46.6$, and $+58.3 \mathrm{~W} \mathrm{~m}^{-2}$. The heating rate in ATM for OPAC mineral (acc. and tran.) modes is about twofold greater than Asian dust cases (PDU and TDU). Such large diabatic heating rates might warm the dust layer and suppress the development of convection under the lower atmosphere, thus exerting profound impacts on the atmospheric dynamic and thermodynamic structures and cloud formation together with the strength and frequency of precipitation occurrence (Rosenfeld et al., 2001; J. Huang et al., 2010; Creamean et al., 2013). Hence, accurate and reliable absorption characteristics of Asian dust should be considered in present-day regional climate models.

\section{Summary}

In this study, we propose two threshold criteria to discriminate two types of Asian dust: Pure Dust (PDU, $\alpha<0.2$ ) and Transported Anthropogenic Dust (TDU, $0.2<\alpha<0.6$ ). PDU can represent nearly "pure" dust in desert source regions and decrease disturbance of other non-dust aerosols, 


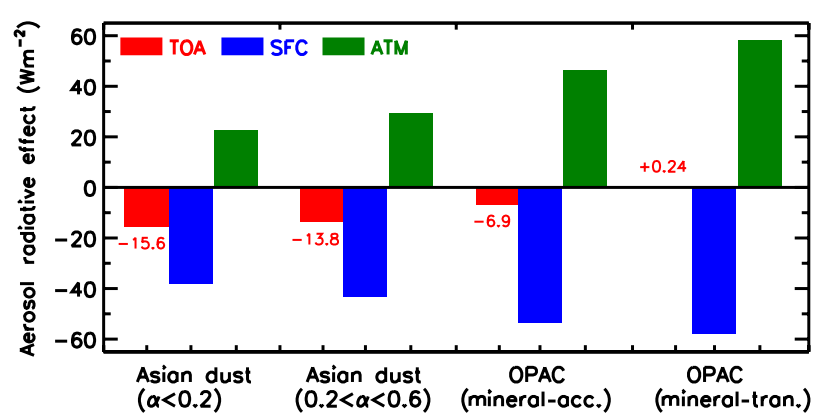

Figure 9. Aerosol shortwave direct radiative effects at the top of the atmosphere (TOA, red color), at the surface (SFC, blue color), and in the atmospheric layer (ATM, green color) for Asian Pure Dust $(\alpha<0.2)$ and Transported Anthropogenic Dust $(0.2<\alpha<0.6)$ computed in this study. Corresponding values for OPAC mineralaccumulated (mineral-acc.) and mineral-transported (mineral-tran.) modes are also presented for comparison.

which would also exclude some fine modes of dust particles. The spectral behaviors of TDU exhibit similar variations with PDU, but they show much stronger absorption and weaker scattering than PDU cases. There are two markedly identifiable characteristics for Asian PDU. (1) Spectral SSA values systematically increase with wavelength from 440 to $675 \mathrm{~nm}$ and remain almost neutral or slightly increase for wavelengths greater than $675 \mathrm{~nm}$, whereas an opposite pattern is shown for the imaginary part of refractive index. (2) Asian Pure Dust aerosols have $\mathrm{AE}$ values smaller than 0.2 and AAE larger than 1.50. Compared with current common dust models (e.g., OPAC and WMO), Asian dust aerosol has relatively weak absorption for wavelengths greater than $550 \mathrm{~nm}$ (SSA $\sim 0.96-$ 0.99 ), but it shows moderate absorption in the blue spectral range $\left(\mathrm{SSA}_{440} \sim 0.92-0.93\right)$. The overall average values of SSA, ASY, Re, and Ri at $550 \mathrm{~nm}$ wavelength for Asian PDU are $0.935 \pm 0.014,0.742 \pm 0.008,1.526 \pm 0.029$, and $0.00226 \pm 0.00056$, respectively, while corresponding values are $0.921 \pm 0.021,0.723 \pm 0.009,1.521 \pm 0.025$, and $0.00364 \pm 0.0014$ for TDU.

It should be noted that the definition of anthropogenic dust in this paper is ambiguous, and TDU here represents more accurately dominant dust mixing with other anthropogenic aerosols. It is very difficult to quantify the anthropogenic contribution due to large uncertainties in defining the anthropogenic fraction of ambient dust burden (Sokolik et al., 2001; Huang et al., 2015). Diverse human activities (e.g., agricultural cultivation, desertification, industrial activity, transportation, and construction in urbanization) in vulnerable environments might modify the land use and Earth's surface cover, and would affect the frequency and intensity of anthropogenic dust. Hence, the optical features of anthropogenic dust aerosols are dependent on the source regions and chemical compositions. However, as concluded by
Huang et al. (2015), anthropogenic dust generated by human activities mainly comes from semiarid and semi-humid regions (Guan et al., 2016) and is generally mixed with other types of aerosols within the PBL. Furthermore, we primarily investigated dust aerosols in arid or semiarid regions over East and Central Asia, which are somewhat disturbed by human activities. Therefore, the key optical properties of TDU derived from this study should to some extent contain the anthropogenic fraction. To fully elucidate exact optical properties of anthropogenic dust, we need to explore detailed morphology, mineralogy, and chemical compositions by means of in situ measurements, laboratory analysis, active and passive remote sensing methods (e.g., multiwavelength lidar, AERONET, MODIS), and model calculations.

\section{Data availability}

The AOD and aerosol inversion products used in this paper can be accessed and freely downloaded from the AERONET home page (Goddard Space Flight Center/NASA, 2016): http://aeronet.gsfc.nasa.gov/.

Acknowledgements. This work was jointly supported by the National Science Foundation of China (41521004, 41305025, 41575015 and 41405113), the Fundamental Research Funds for the Central Universities lzujbky-2015-4 and lzujbky-2016k01, and the China 111 Project (No. B 13045). We thank the GSFC/NASA AERONET group for processing the AERONET data (http://aeronet.gsfc.nasa.gov). The authors would like to express special thanks to the principal investigators (HongBin Chen, Philippe Goloub, Bernadette Chatenet, Xiao-Ye Zhang, Laurent Gomes, Sabur F. Abdullaev, and Hamid Khalesifard) and their staff for effort in establishing and maintaining the instruments at AERONET sites used in this work. We appreciate the MODIS and TOMS teams for supplying the satellite data. We would also like to thank all anonymous reviewers for their constructive and insightful comments.

Edited by: K. Kai

Reviewed by: three anonymous referees

\section{References}

Alam, K., Trautmann, T., and Blaschke, T.: Aerosol optical properties and radiative forcing over mega-city Karachi, Atmos. Res., 101, 773-782, doi:10.1016/j.atmosres.2011.05.007, 2011.

Alfaro, S. C., Lafon, S., Rajot, J. L., Formenti, P., Gaudichet, A., and Maillé, M.: Iron oxides and light absorption by pure desert dust: An experimental study, J. Geophys. Res., 109, D08208, doi:10.1029/2003JD004374, 2004.

Alizadeh Choobari, O., Zawar-Reza, P., and Sturman, A.: The global distribution of mineral dust and its impacts on the climate system: A review, Atmos. Res., 138, 152-165, doi:10.1016/j.atmosres.2013.11.007, 2014. 
Aoki, T., Motoyoshi, H., Kodama, Y., Yasunari, T. J., Sugiura, K., and Kobayashi, H.: Atmospheric aerosol deposition on snow surfaces and its effect on albedo, SOLA, 2, 13-16, doi:10.2151/sola.2006-004, 2006.

Arimoto, R., Zhang, X. Y., Huebert, B. J., Kang, C. H., Savoie, D. L., Prospero, J. M., Sage, S. K., Schloesslin, C. A., Khaing, H. M., and Oh, S. N.: Chemical composition of atmospheric aerosols from Zhenbeitai, China, and Gosan, South Korea, during ACE-Asia, J. Geophys. Res., 109, D19S04, doi:10.1029/2003JD004323, 2004.

Bi, J., Huang, J., Fu, Q., Wang, X., Shi, J., Zhang, W., Huang, Z., and Zhang B.: Toward characterization of the aerosol optical properties over Loess Plateau of Northwestern China, J. Quant. Spectrosc. Ra., 112, 346-360, doi:10.1016/j.jqsrt.2010.09.006, 2011

Bi, J., Huang, J., Fu, Q., Ge, J., Shi, J., Zhou, T., and Zhang, W.: Field measurement of clear-sky solar irradiance in Badain Jaran Desert of Northwestern China, J. Quant. Spectrosc. Ra., 122, 194-207, doi:10.1016/j.jqsrt.2012.07.025, 2013.

Bi, J., Shi, J., Xie, Y., Liu, Y., Takamura, T., and Khatri, P.: Dust aerosol characteristics and shortwave radiative impact at a Gobi Desert of Northwest China during the spring of 2012, J. Meteorol. Soc. Jpn., 92A, 33-56, doi:10.2151/jmsj.2014-A03, 2014.

Carlson, T. N. and Caverly, R. S.: Radiative characteristics of Saharan dust at solar wavelengths, J. Geophys. Res., 82, 3141-3152, 1977.

Chan, C.-C., Chuang, K.-J., Chen, W.-J., Chang, W.-T., Lee, C.-T., and Peng, C.-M.: Increasing cardiopulmonary emergency visits by long-range transported Asian dust storms in Taiwan, Environ. Res., 106, 393-400, 2008.

Charlson, R. J., Schwartz, S. E., Hales, J. M., Cess, R. D., Coakley Jr., J. A., Hansen, J. E., and Hofmann, D. J.: Climate forcing by anthropogenic aerosols, Science, 255, 423-430, doi:10.1126/science.255.5043.423, 1992.

Che, H., Shi, G., Uchiyama, A., Yamazaki, A., Chen, H., Goloub, P., and Zhang, X.: Intercomparison between aerosol optical properties by a PREDE skyradiometer and CIMEL sunphotometer over Beijing, China, Atmos. Chem. Phys., 8, 3199-3214, doi:10.5194/acp-8-3199-2008, 2008.

Che, H., Zhang, X., Chen, H., Damiri, B., Goloub, P., Li, Z., Zhang, X., Wei, Y., Zhou, H., Dong, F., Li, D., and Zhou, T.: Instrument calibration and aerosol optical depth validation of the China Aerosol Remote Sensing Network, J. Geophys. Res., 114, D03206, doi:10.1029/2008JD011030, 2009a.

Che, H., Zhang, X., Alfraro, S., Chatenet, B., Gomes, L., and Zhao, J.: Aerosol optical properties and its radiative forcing over Yulin, China in 2001 and 2002, Adv. Atmos. Sci., 26, 564-576, doi:10.1007/s00376-009-0564-4, 2009b.

Che, H., Wang, Y., Sun, J., Zhang, X., Zhang, X., and Guo, J.: Variation of aerosol optical properties over the Taklimakan Desert in China, Aerosol Air Qual. Res., 13, 777-785, doi:10.4209/aaqr.2012.07.0200, 2013.

Che, H., Xia, X., Zhu, J., Li, Z., Dubovik, O., Holben, B., Goloub, P., Chen, H., Estelles, V., Cuevas-Agulló, E., Blarel, L., Wang, H., Zhao, H., Zhang, X., Wang, Y., Sun, J., Tao, R., Zhang, X., and Shi, G.: Column aerosol optical properties and aerosol radiative forcing during a serious haze-fog month over North China Plain in 2013 based on ground-based sunphotometer measure- ments, Atmos. Chem. Phys., 14, 2125-2138, doi:10.5194/acp14-2125-2014, 2014.

Che, H., Zhang, X.-Y., Xia, X., Goloub, P., Holben, B., Zhao, H., Wang, Y., Zhang, X.-C., Wang, H., Blarel, L., Damiri, B., Zhang, R., Deng, X., Ma, Y., Wang, T., Geng, F., Qi, B., Zhu, J., Yu, J., Chen, Q., and Shi, G.: Ground-based aerosol climatology of China: aerosol optical depths from the China Aerosol Remote Sensing Network (CARSNET) 2002-2013, Atmos. Chem. Phys., 15, 7619-7652, doi:10.5194/acp-15-7619-2015, 2015.

Chin, M., Diehl, T., Dubovik, O., Eck, T. F., Holben, B. N., Sinyuk, A., and Streets, D. G.: Light absorption by pollution, dust, and biomass burning aerosols: a global model study and evaluation with AERONET measurements, Ann. Geophys., 27, 3439-3464, doi:10.5194/angeo-27-3439-2009, 2009.

Claquin, T., Schulz, M., Balkanski, Y., and Boucher, O.: Uncertainties in assessing radiative forcing by mineral dust, Tellus B, 50, 491-505, 1998.

Claquin, T., Schulz, M., and Balkanski, Y.: Modeling the mineralogy of atmospheric dust sources, J. Geophys. Res., 104, 22243 22256, 1999.

Creamean, J. M., Suski, K. J., Rosenfeld, D., Cazorla, A., DeMott, P. J., Sullivan, R. C., White, A. B., Ralph, F. M., Minnis, P., Comstock, J. M., Tomlinson, J. M., and Prather, K. A.: Dust and biological aerosols from the Sahara and Asia influence precipitation in the western U.S., Science, 339, 1572-1578, doi:10.1126/science.1227279, 2013.

DeMott, P. J., Sassen, K., Poellot, M. R., Baumgardner, D., Rogers, D. C., Brooks, S. D., Prenni, A. J., and Kreidenweis, S. M.: African dust aerosols as atmospheric ice nuclei, Geophys. Res. Lett., 30, 1732, doi:10.1029/2003GL017410, 2003.

Dubovik, O. and King, M. D.: A flexible inversion algorithm for retrieval of aerosol optical properties from Sun and sky radiance measurements, J. Geophys. Res., 105, 20673-20696, doi:10.1029/2000JD900282, 2000.

Dubovik, O., Smirnov, A., Holben, B. N., King, M. D., Kaufman, Y. J., Eck, T. F., and Slutsker, I.: Accuracy assessments of aerosol optical properties retrieved from Aerosol Robotic Network (AERONET) Sun and sky radiance measurements, J. Geophys. Res., 105, 9791-9806, doi:10.1029/2000JD900040, 2000.

Dubovik, O., Holben, B. N., Lapyonok, T., Sinyuk, A., Mishchenko, M. I., Yang, P., and Slutsker, I.: Non-spherical aerosol retrieval method employing light scattering by spheroids, Geophys. Res. Lett., 29, 1415, doi:10.1029/2001GL014506, 2002a.

Dubovik, O., Holben, B. N., Eck, T. F., Smirnov, A., Kaufman, Y. J., King, M. D., Tanré, D., and Slutsker, I.: Variability of absorption and optical properties of key aerosol types observed in worldwide locations, J. Atmos. Sci., 59, 590-608, 2002 b.

Dubovik, O., Sinyuk, A., Lapyonok, T. Holben, B. N., Mishchenko, M., Yang, P., Eck, T. F., Volten, H., Muñoz, O., Veihelmann, B., van der Zande, W. J., Leon, J.-F., Sorokin, M., and Slutsker, I.: Application of spheroid models to account for aerosol particle nonsphericity in remote sensing of desert dust, J. Geophys. Res., 111, D11208, doi:10.1029/2005JD006619, 2006.

Eck, T. F., Holben, B. N., Reid, J. S., Dubovik, O., Smirnov, A., O’Neill, N. T., Slutsker, I., and Kinne, S.: Wavelength dependence of the optical depth of biomass burning, urban and desert dust aerosols, J. Geophys. Res., 104, 31333-31350, 1999.

Eck, T. F., Holben, B. N., Dubovik, O., Smirnov, A., Goloub, P., Chen, H. B., Chatenet, B., Gomes, L., Zhang, X.-Y, Tsay, S.- 
C., Ji, Q., Giles, D., and Slutsker, I.: Columnar aerosol optical properties at AERONET sites in central eastern Asia and aerosol transport to the tropical mid-Pacific, J. Geophys. Res., 110, D06202, doi:10.1029/2004JD005274, 2005.

Fu, Q., Thorsen, T., Su, J., Ge, J., and Huang, J.: Test of Mie-based single-scattering properties of non-spherical dust aerosols in radiative flux calculations, J. Quant. Spectrosc. Ra., 110, 16401653, doi:10.1016/j.jqsrt.2009.03.010, 2009.

Ge, J., Su, J., Ackerman, T. P., Fu, Q., Huang, J., and Shi, J.: Dust aerosol optical properties retrieval and radiative forcing over northwest China during the 2008 ChinaU.S. joint field experiment, J. Geophys. Res., 115, D00K12, doi:10.1029/2009JD013263, 2010.

Ginoux, P., Prospero, J. M., Gill, T. E., Hsu, N. C., and Zhao, M.: Global-scale attribution of anthropogenic and natural sources and their emission rates based on MODIS Deep Blue aerosol products, Rev. Geophys., 50, RG3005, doi:10.1029/2012RG000388, 2012.

Goddard Space Flight Center/NASA: AERONET dataset, available at: http://aeronet.gsfc.nasa.gov/, last access: 15 December 2016.

Golitsyn, G. and Gillette, D. A.: Introduction: A joint SovietAmerican experiment for the study of Asian desert dust and its impact on local meteorological conditions and climate, Atmos. Environ., 27A, 2467-2470, 1993.

Guan, X., Huang, J., Guo, N., Bi, J., and Wang, G.: Variability of soil moisture and its relationship with surface albedo and soil thermal parameters over the Loess Plateau, Adv. Atmos. Sci., 26, 692-700, doi:10.1007/s00376-009-8198-0, 2009.

Guan, X., Huang, J., Zhang, Y., Xie, Y., and Liu, J.: The relationship between anthropogenic dust and population over global semi-arid regions, Atmos. Chem. Phys., 16, 5159-5169, doi:10.5194/acp-16-5159-2016, 2016.

Halthore, R. N., Crisp, D., Schwartz, S. E., Anderson, G. P., Berk, A., Bonnel, B., Boucher, O., Chang, F.-L., Chou, M.-D., Clothiaux, E. E., Dubuisson, P., Fomin, B., Fouquart, Y., Freidenreich, S., Gautier, C., Kato, S., Laszlo, I., Li, Z., Mather, J. H., Plana-Fattori, A., Ramaswamy, V., Ricchiazzi, P., Shiren, Y., Trishchenko, A., and Wiscombe, W.: Intercomparison of shortwave radiative transfer codes and measurements, J. Geophys. Res., 110, D11206, doi:10.1029/2004JD005293, 2005.

Hansen, J., Sato, M., and Ruedy, R.: Radiative forcing and climate response, J. Geophys. Res., 102, 6831-6864, 1997.

Hess, M., Kopke, P., and Schult, I.: Optical properties of aerosols and clouds: The software package OPAC, B. Am. Meteorol. Soc., 79, 831-844, 1998.

Holben, B. N., Eck, T. F., Slutsker, I., Tanre, D., Buis, J. P., Setzer, A., Vermote, E., Reagan, J. A., Kaufman, Y. J., Nakajima, T., Lavenu, F., Jankowiak, F., and Smirnov, A., AERONET - A federated instrument network and data archive for aerosol characterization, Remote Sens. Environ., 66, 1-16, 1998.

Huang, J., Minnis, P., Lin, B., Yi, Y., Khaiyer, M. M., Arduini, R. F., Fan, A., and Mace, G. G.: Advanced retrievals of multilayered cloud properties using multispectral measurements, J. Geophys. Res., 110, D15S18, doi:10.1029/2004JD005101, 2005.

Huang, J., Lin, B., Minnis, P., Wang, T., Wang, X., Hu, Y., Yi, Y., and Ayers, J. K.: Satellite-based assessment of possible dust aerosols semi-direct effect on cloud water path over East Asia, Geophys. Res. Lett., 33, L19802, doi:10.1029/2006GL026561, 2006.
Huang, J., Minnis, P., Chen, B., Huang, Z., Liu, Z., Zhang, Q., Yi, Y., and Ayers, J. K.: Long-range transport and vertical structure of Asian dust from CALIPSO and surface measurements during PACDEX, J. Geophys. Res., 113, D23212, doi:10.1029/2008JD010620, 2008a.

Huang, J., Zhang, W., Zuo, J., Bi, J., Shi, J., Wang, X., Chang, Z., Huang, Z., Yang, S., Zhang, B., Wang, G., Feng, G., Yuan, J., Zhang, L., Zuo, H., Wang, S., Fu, C., and Chou, J.: An overview of the semi-arid climate and environment research observatory over the Loess Plateau, Adv. Atmos. Sci., 25, 906-921, doi:10.1007/s00376-008-0906-7, 2008b.

Huang, J., Fu, Q., Su, J., Tang, Q., Minnis, P., Hu, Y., Yi, Y., and Zhao, Q.: Taklimakan dust aerosol radiative heating derived from CALIPSO observations using the Fu-Liou radiation model with CERES constraints, Atmos. Chem. Phys., 9, 4011-4021, doi:10.5194/acp-9-4011-2009, 2009.

Huang, J., Minnis, P., Yan, H., Yi, Y., Chen, B., Zhang, L., and Ayers, J. K.: Dust aerosol effect on semi-arid climate over Northwest China detected from A-Train satellite measurements, Atmos. Chem. Phys., 10, 6863-6872, doi:10.5194/acp-10-68632010, 2010.

Huang, J., Fu, Q., Zhang, W., Wang, X., Zhang, R., Ye, H., and Warren, S. G.: Dust and black carbon in seasonal snow across northern China, B. Am. Meteorol. Soc., 92, 175-181, doi:10.1175/2010BAMS3064.1, 2011.

Huang, J., Wang, T., Wang, W., Li, Z., and Yan, H.: Climate effects of dust aerosols over East Asian arid and semiarid regions, J. Geophys. Res., 119, 11398-11416, doi:10.1002/2014JD021796, 2014.

Huang, J., Yu, H., Guan, X., Wang, G., and Guo, R.: Accelerated dryland expansion under climate change, Nature Clim. Change, 6, 166-171, doi:10.1038/nclimate2837, 2016.

Huang, J. P., Liu, J. J., Chen, B., and Nasiri, S. L.: Detection of anthropogenic dust using CALIPSO lidar measurements, Atmos. Chem. Phys., 15, 11653-11665, doi:10.5194/acp-1511653-2015, 2015.

Huang, Z., Huang, J., Bi, J., Wang, G., Wang, W., Fu, Q., Li, Z., Tsay, S.-C., and Shi, J.: Dust aerosol vertical structure measurements using three MPL lidars during 2008 China-U.S. joint dust field experiment, J. Geophys. Res., 115, D00K15, doi:10.1029/2009JD013273, 2010.

Huebert, B. J., Bates, T., Russell, P. B., Shi, G., Kim, Y. J., Kawamura, K., Carmichael, G., and Nakajima, T.: An overview of ACE-Asia: Strategies for quantifying the relationships between Asian aerosols and their climatic impacts, J. Geophys. Res., 108, 8633, doi:10.1029/2003JD003550, 2003.

Husar, R. B., Tratt, D. M., and Schichtel, B. A., et al.: Asian dust events of April 1998, J. Geophys. Res., 106, 18317-18330, 2001.

Jickells, T., An, Z., Andersen, K., Baker, A., Bergametti, G., Brooks, N., Cao, J., Boyd, P., Duce, R., Hunter, K., Kawahata, H., Kubilay, N., laRoche, J., Liss, P., Mahowald, N., Prospero, J., Ridgwell, A., Tegen, I., and Torres, R.: Global iron connections between desert dust, ocean biogeochemistry, and climate, Science, 308, 67-71, doi:10.1126/science.1105959, 2005.

Kim, D., Chin, M., Yu, H., Eck, T. F., Sinyuk, A., Smirnov, A., and Holben, B. N.: Dust optical properties over North Africa and Arabian Peninsula derived from the AERONET dataset, Atmos. Chem. Phys., 11, 10733-10741, doi:10.5194/acp-1110733-2011, 2011. 
Kim, D.-H., Sohn, B.-J., Nakajima, T., Takamura, T., Takemura, T., Choi, B.-C., and Yoon, S.-C.: Aerosol optical properties over east Asia determined from ground-based sky radiation measurements, J. Geophys. Res., 109, D02209, doi:10.1029/2003JD003387, 2004.

Kinne, S., Schulz, M., Textor, C., Guibert, S., Balkanski, Y., Bauer, S. E., Berntsen, T., Berglen, T. F., Boucher, O., Chin, M., Collins, W., Dentener, F., Diehl, T., Easter, R., Feichter, J., Fillmore, D., Ghan, S., Ginoux, P., Gong, S., Grini, A., Hendricks, J., Herzog, M., Horowitz, L., Isaksen, I., Iversen, T., Kirkevåg, A., Kloster, S., Koch, D., Kristjansson, J. E., Krol, M., Lauer, A., Lamarque, J. F., Lesins, G., Liu, X., Lohmann, U., Montanaro, V., Myhre, G., Penner, J., Pitari, G., Reddy, S., Seland, O., Stier, P., Takemura, T., and Tie, X.: An AeroCom initial assessment - optical properties in aerosol component modules of global models, Atmos. Chem. Phys., 6, 1815-1834, doi:10.5194/acp-6-1815-2006, 2006.

Lafon, S., Rajot, J.-L., Alfaro, S. C., and Gaudichet, A.: Quantification of iron oxides in desert aerosol, Atmos. Environ., 38, 12111218, 2004.

Lafon, S., Sokolik, I. N., Rajot, J. L., Caquineau, S., and Guadichet, A.: Characterization of iron oxides in mineral dust aerosols: Implications for light absorption, J. Geophys. Res., 111, D21207, doi:10.1029/2005JD007016, 2006.

Li, Z., Li, C., Chen, H., Tsay, S.-C., Holben, B., Huang, J., Li, B., Maring, H., Qian, Y., Shi, G., Xia, X., Yin, Y., Zheng, Y., and Zhuang, G.: East Asian Studies of Tropospheric Aerosols and their Impact on Regional Climate (EAST-AIRC): An overview, J. Geophys. Res., 116, D00K34, doi:10.1029/2010JD015257, 2011

Mikami, M., Shi, G. Y., Uno, I., Yabuki, S., Iwasaka, Y., Yasui, M., Aoki, T., Tanaka, T. Y., Kurosaki, Y., Masuda, K., Uchiyama, A., Matsuki, A., Sakai, T., Takemi, T., Nakawo, M., Seino, N., Ishizuka, M., Satake, S., Fujita, K., Hara, Y., Kai, K., Kanayama, S., Hayashi, M., Du, M., Kanai, Y., Yamada, Y., Zhang, X. Y., Shen, Z., Zhou, H., Abe, Q., Nagai, T., Tsutsumi, Y., Chiba, M., and Suzuki, J.: Aeolian dust experiment on climate impact: An overview of Japan-China joint project ADEC, Global Planet. Change, 52, 142-172, doi:10.1016/j.gloplacha.2006.03.001, 2006.

Morman, S. A. and Plumlee, G. S.: The role of airborne mineral dusts in human disease, Aeolian Res., 9, 203-212, 2013.

Nakajima, T., Tonna, G., Rao, R., Boi, P., Kaufman, Y., and Holben, B.: Use of sky brightness measurements from ground for remote sensing of particulate polydispersions, Appl. Optics, 35, 26722686, doi:10.1364/AO.35.002672, 1996.

Nakajima, T., Sekiguchi, M., Takemura, T., Uno, I., Higurashi, A., Kim, D., Sohn, B. J., Oh, S.-N., Nakajima, T. Y., Ohta, S., Okada, I., Takamura, T., and Kawamoto, K.: Significance of direct and indirect radiative forcings of aerosols in the East China Sea region, J. Geophys. Res., 108, 8658, doi:10.1029/2002JD003261, 2003

Okin, G. S., Mahowald, N., Chadwick, O. A., and Artaxo, P.: Impact of desert dust on the biogeochemistry of phosphorus in terrestrial ecosystems, Global Biogechem. Cycles, 18, GB2005, doi:10.1029/2003GB002145, 2004.

Pandithurai, G., Dipu, S., Dani, K. K., Tiwari, S., Bisht, D. S., Devara, P. C. S., and Pinker, R. T.: Aerosol radiative forcing dur- ing dust events over New Delhi, India, J. Geophys. Res., 113, D13209, doi:10.1029/2008JD009804, 2008.

Patterson, E. M., Gillette, D. A., and Stockton, B.: Complex index of refraction between 300 and $700 \mathrm{~nm}$ for Saharan aerosols, J. Geophys. Res., 82, 3153-3160, 1977.

Perlwitz, J., Tegen, I., and Miller, R. L.: Interactive soil dust aerosol model in GISS GCM, 1. Sensitivity of the soil dust cycle to radiative properties of soil dust aerosols, J. Geophys. Res., 106, 18167-18192, 2001.

Prospero, J. M., Ginoux, P., Torres, O., Nicholson, S. E., and Gill, T. E.: Environmental characterization of global sources of atmospheric soil dust identified with the Nimbus 7 total ozone mapping spectrometer (TOMS) absorbing aerosol product, Rev. Geophys., 40, 1002, doi:10.1029/2000RG000095, 2002.

Ramanathan, V., Crutzen, P. J., Kiehl, J. T., and Rosenfeld, D.: Aerosols, climate, and the hydrological cycle, Science, 294, 2119-2124, doi:10.1126/science.1064034, 2001.

Ricchiazzi, P., Yang, S., Gautier, C., and Sowle, D.: SBDART: A research and teaching software tool for plane-parallel radiative transfer in the Earth's atmosphere, B. Am. Meteorol. Soc., 79, 2101-2114, 1998.

Rosenfeld, D., Rudich, Y., and Lahav, R.: Desert dust suppressing precipitation: A possible desertification feedback loop, P. Natl. Acad. Sci. USA, 98, 5975-5980, 2001.

Shao, Y., Wyrwoll, K.-H., Chappel, A., Huang, J., Lin, Z., McTainsh, G., Mikami, M., Tanaka, T., Wang, X., and Yoon, S.: Dust cycle: An emerging core theme in Earth system science, Aeolian Res., 2, 181-204, 2011.

Shen, Z., Sun, J., Cao, J., Zhang, L., Zhang, Q., Lei, Y., Gao, J., Huang, R., Liu, S., Huang, Y., Zhu, C., Xu, H., Zheng, C., Liu, P., and Xue, Z.: Chemical profiles of urban fugitive dust $\mathrm{PM}_{2.5}$ samples in Northern Chinese cities, Sci. Total Environ., 569-570, 619-626, doi:10.1016/j.scitotenv.2016.06.156, 2016.

Smirnov, A., Holben, B. N., Eck, T. F., Dubovik, O., and Slutsker, I.: Cloud screening and quality control algorithms for the AERONET database, Remote Sens. Environ., 73, 337-349, 2000.

Smirnov, A., Holben, B. N., Kaufman, Y. J., Dubovik, O., Eck, T. F., Slutsker, I., Pietras, C., and Halthore, R.: Optical properties of atmospheric aerosol in maritime environments, J. Atmos. Sci., 59, 501-523, 2002.

Sokolik, I. N. and Golitsyn, G.: Investigation of optical and radiative properties of atmospheric dust aerosols, Atmos. Environ., 27A, 2509-2517, 1993.

Sokolik, I. N. and Toon, O. B.: Incorporation of mineralogical composition into models of the radiative properties of mineral aerosol from UV to IR wavelengths, J. Geophys. Res., 104, 9423-9444, 1999.

Sokolik, I. N., Winker, D. M., Bergametti, G., Gillette, D. A., Garmichael, G., Kaufman, Y. J., Gomes, L., Schuetz, L., and Penner, J. E.: Introduction to special section: Outstanding problems in quantifying the radiative impacts of mineral dust, J. Geophys. Res., 106, 18015-18027, 2001.

Takamura, T., Nakajima, T., and SKYNET community group: Overview of SKYNET and its Activities, Opt. Puray Apl., 37, 3303-3308, 2004.

Tegen, I. and Fung, I.: Contribution to the atmospheric mineral aerosol load from land surface modification, J. Geophys. Res., 100, 18707-18726, doi:10.1029/95JD02051, 1995. 
Todd, M. C., Washington, R., Martins, J. V., Dubovik, O., Lizcano, G., M'Bainayel, S., and Engelstaedter, S.: Mineral dust emission from the Bodélé Depression, northern Chad, during BoDEx 2005, J. Geophys. Res., 112, D06207, doi:10.1029/2006JD007170, 2007.

Uchiyama, A., Yamazaki, A., Togawa, H., Asano, J., and Shi, G.Y.: Single scattering albedo of Aeolian dust as inferred from sky-radiometer and in situ ground-based measurement, SOLA, 1, 209-212, doi:10.2151/sola.2005-054, 2005.

Uno, I., Eguchi, K., Yumimoto, K., Takemura, T., Shimizu, A., Uematsu, M., Liu, Z., Wang, Z., Hara, Y., and Sugimoto, N.: Asian dust transported one full circuit around the globe, Nat. Geosci., 2, 557-560, doi:10.1038/NGEO583, 2009.

Uno, I., Eguchi, K., Yumimoto, K., Liu, Z., Hara, Y., Sugimoto, N., Shimizu, A., and Takemura, T.: Large Asian dust layers continuously reached North America in April 2010, Atmos. Chem. Phys., 11, 7333-7341, doi:10.5194/acp-11-7333-2011, 2011.

Wang, G., Huang, J., Guo, W., Zuo, J., Wang, J., Bi, J., Huang, Z., and Shi, J.: Observation analysis of land-atmosphere interactions over the Loess Plateau of northwest China, J. Geophys. Res., 115, D00K17, doi:10.1029/2009JD013372, 2010.

Wang, H., Shi, G. Y., Aoki, T., Wang, B., and Zhao, T. L.: Radiative forcing due to dust aerosol over east Asia-north Pacific region during spring, 2001, Chin. Sci. Bull., 49, 2212-2219, 2004.

Wang, H., Zhang, X., Gong, S., Chen, Y., Shi, G., and Li, W.: Radiative feedback of dust aerosols on the East Asian dust storms, J. Geophys. Res., 115, D23214, doi:10.1029/2009JD013430, 2010.

Wang, W., Huang, J., Minnis, P., Hu, Y., Li, J., Huang, Z., Ayers, J. K., and Wang, T.: Dusty cloud properties and radiative forcing over dust source and downwind regions derived from A-Train data during the Pacific Dust Experiment, J. Geophys. Res., 115, D00H35, doi:10.1029/2010JD014109, 2010.

Wang, X., Huang, J., Ji, M., and Higuchi, K.: Variability of East Asia dust events and their long-term trend, Atmos. Environ., 42, 3156-3165, doi:10.1016/j.atmosenv.2007.07.046, 2008.

Wang, X., Doherty, S. J., and Huang, J.: Black carbon and other light-absorbing impurities in snow across Norhtern China, J. Geophys. Res., 118, 1471-1492, doi:10.1029/2012JD018291, 2013.
Wang, X., Pu, W., Shi, J., Bi, J., Zhou, T., Zhang, X., and Ren, Y.: A comparison of the physical and optical properties of anthropogenic air pollutants and mineral dust over Northwest China, J. Meteorol. Res., 29, 180-200, doi:10.1007/s13351-015-4092$0,2015$.

Wang, Y., Wang, R., Ming, J., Liu, G., Chen, T., Liu, X., Liu, H., Zhen, Y., and Cheng, G.: Effects of dust storm events on weekly clinic visits related to pulmonary tuberculosis disease in Minqin, China, Atmos. Environ., 127, 205-212, 2016.

World Meteorological Organization (WMO): WCP-55: World Climate Research report of the experts meeting on aerosols and their climatic effects, edited by: Deepak, A. and Gerber, H. E., Williamsburg, Virginia, USA, 107 pp., 1983.

Wu, F., Zhang, D., Cao, J., Xu, H., and An, Z.: Soil-derived sulfate in atmospheric dust particles at Taklimakan desert, Geophys. Res. Lett., 39, L24803, doi:10.1029/2012GL054406, 2012.

Wu, F., Zhang, D., Cao, J., Zhang, T., and An, Z.: Background-like nitrate in desert air, Atmos. Environ., 84, 39-43, 2014.

Xia, X., Chen, H., Goloub, P., Zhang, W., Chatenet, B., and Wang, P.: A compilation of aerosol optical properties and calculation of direct radiative forcing over an urban region in northern China, J. Geophys. Res., 112, D12203, doi:10.1029/2006JD008119, 2007.

Xu, J., Bergin, M. H., Greenwald, R., Schauer, J. J., Shafer, M. M., Jaffrezo, J. L., and Aymoz, G.: Aerosol chemical, physical, and radiative characteristics near a desert source region of northwest China during ACE-Asia, J. Geophys. Res., 109, D19S03, doi:10.1029/2003JD004239, 2004.

Yang, M., Howell, S. G., Zhuang, J., and Huebert, B. J.: Attribution of aerosol light absorption to black carbon, brown carbon, and dust in China - interpretations of atmospheric measurements during EAST-AIRE, Atmos. Chem. Phys., 9, 2035-2050, doi:10.5194/acp-9-2035-2009, 2009.

Zhang, X., Arimoto, R., and An, Z.: Dust emission from Chinese desert sources linked to variations in atmospheric circulation, J. Geophys. Res., 102, 28041-28047, doi:10.1029/97JD02300, 1997.

Zheng, Z., Ren, H., and Huang, J.: Analogue correction of errors based on seasonal climatic predictable components and numerical experiments, Acta Phys. Sin., 58, 7359-7367, 2009. 